Scale matters: The influence of structural inheritance on fracture patterns

Anindita Samsu ${ }^{1}$, Alexander R. Cruden ${ }^{1}$, Steven Micklethwaite ${ }^{1}$, Lachlan Grose ${ }^{1}$, Stefan A. Vollgger ${ }^{1}$

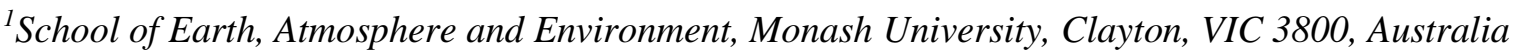

This manuscript is a pre-print and has been accepted for publication in Journal of Structural Geology. 


\section{Scale matters: The influence of structural inheritance on fracture patterns}

2 Anindita Samsu ${ }^{1 *}$, Alexander R. Cruden ${ }^{1}$, Steven Micklethwaite ${ }^{1}$, Lachlan Grose ${ }^{1}$, Stefan A.

$3 \quad$ Vollgger $^{1}$

$4{ }^{1}$ School of Earth, Atmosphere and Environment, Monash University, Clayton, VIC 3800, $5 \quad$ Australia

6

$7 \quad *$ Corresponding author: anindita.samsu@monash.edu

9 Keywords: fractures, faults, structural inheritance, rift basin, Gippsland Basin

\section{ABSTRACT}

12 Fracture systems are often geometrically invariant across a range of scales, but the impact of

13 structural inheritance on this relationship is poorly understood. This paper shows how

14 fracture orientations in sedimentary rocks vary at different scales when influenced by pre-rift

15 basement structures. We use high-resolution unmanned aerial vehicle (UAV) orthophotos to

16 map folds and fractures in the basement and cover rocks of the Gippsland Basin, southeast

17 Australia. Outcrop-scale observations are compared with $>1 \mathrm{~km}$ long faults previously

18 interpreted from potential field data. We use length-coloured rose diagrams of fracture traces

19 to compare trends in fracture orientations. Early Cretaceous syn-rift normal faults exhibit the

20 same ENE-WSW trend at basin $(>1 \mathrm{~km})$ and outcrop (meters) scales. Pervasive outcrop-

21 scale, subvertical, NNW-SSE striking joints record a subsequent regional shortening event, but at the basin scale this is only expressed as reverse reactivated ENE-WSW striking faults. Thus, fabrics and/or faults in the underlying basement exert significant control on the 
orientation of basin-scale fractures in the cover but appear to have limited influence on outcrop-scale fracture orientations. Our observations show that fracture systems influenced by structural inheritance are not scale-invariant, and that a proper understanding of structural architecture can only be achieved by analysing data that span multiple scales.

\section{INTRODUCTION}

Structural inheritance can impact the location, shape, and orientation of entire rift systems (i.e., tectonic inheritance) (Wilson, 1966; Tommasi and Vauchez, 2001; Thomas, 2006; Manatschal et al., 2015; Schiffer et al., 2018; Heron et al., 2019) as well as smaller-scale faults within rift basins (e.g., Corti et al., 2007; Henza et al., 2011; Reeve et al., 2015; Phillips et al., 2018). Mechanical heterogeneities in pre-rift "basement" rocks can interact with farfield stress during the formation and evolution of a rift basin, influencing fracturing (including faulting) in the sedimentary "cover" rocks. At the scale of an individual basin, one form of interaction between the basement and cover is the reactivation of basement faults and shear zones (McCaffrey, 1997; Holdsworth et al., 2001; Kirkpatrick et al., 2013; Phillips et al., 2016). The presence of such weakened zones in the crust results in a competition between the nucleation of new fractures and failure along a pre-existing zone with a lower shear strength under a particular stress field (Byerlee, 1978; Sibson, 1985). Reactivation may then lead to the formation faults in the cover that are parallel to the pre-existing structure (Holdsworth et al., 1997) and oblique to their expected orientation under an inferred paleoextension direction (e.g., Corti et al., 2007).

Another form of structural inheritance is recognised when the trend of fracture traces in the cover appear to change across areas that overlie different basement domains, even when the fractures do not directly link into the basement structures (Wilson et al., 2010; Samsu et al., 2019). The mechanism behind these variable fracture orientations is unclear but may be the 
result of local stress perturbations in the vicinity of pre-existing structures, which alter stress trajectories (Bourne and Willemse, 2001; Maerten et al., 2002; de Joussineau et al., 2003; Morley, 2010) and are reflected by a local rotation of the strain axes. Nevertheless, this second, poorly understood mechanism of inheritance can have a significant impact on fracture orientations and connectivity.

Few studies examine the influence of inheritance on the formation of fractures in one study area at multiple scales. In a study of the northeast Brazilian margin, Kirkpatrick et al. (2013) found that the orientation of regional rift faults are parallel to sub-vertical, crustal-scale shear zones in the basement, while syn-rift outcrop-scale faults are oblique to the shear zones and the pervasive basement fabric. Their findings suggest that the influence of pre-existing basement structures is scale-dependent. However, it is rarely the case that structures in basement rocks can be compared with the overlying cover rocks at the same scale. The interpretation of faults in cover rocks is usually conducted on seismic reflection data (e.g, Peace et al., 2018; Phillips et al., 2016; Reeve et al., 2015), while basement structures at the margins of rift basins are observed in outcrops (e.g., Wilson et al., 2006; Kirkpatrick et al., 2013).

Our study uses the Cretaceous western onshore Gippsland Basin (southeast Australia; Fig. 1) as a natural laboratory to investigate how pre-existing discrete faults and a pervasive fabric in the basement may have influenced fracture orientations in the overlying cover rocks. Here, we define the basement as any rock unit below the overlying cover. The onshore Gippsland Basin provides a unique opportunity to study the various scales at which inheritance operates. Firstly, the two known levels of basement underneath the basin - a Paleozoic basement and its underlying Neoproterozoic-Cambrian basement - allow us to study multiple orders of inherited structures. Secondly, onshore exposure of basement and cover rocks along the coast allow us to directly compare structures in basement and cover rocks at the same scale. 
We used high-resolution unmanned aerial vehicle (UAV) orthophotos of outcrops to map preexisting structures in the basement and thousands of fractures in the cover rocks. Maps of fracture traces (including faults and joints) and orientation statistics of fracture data were used to separate regional fracture trends from local trends. In this paper, we compare existing interpretations of basin-scale ( $>1 \mathrm{~km}$ scale) faults with the outcrop-scale fracture data. Using field observations, we present possible hypotheses of how discrete discontinuities or pervasive mechanical anisotropies in the basement, such as bedding, fold axial planar foliations, faults, and rheological boundaries, affect deformation in the cover rocks during the syn-rift and post-rift (inversion) stages of basin development. Our findings show that the orientations of fractures that have been influenced by pre-existing basement structures vary between scales of observation.

\section{GEOLOGICAL SETTING}

\subsection{Structural elements and evolution of the Gippsland Basin}

The Gippsland Basin is part of the Australian Southern Margin rift system, which formed during Jurassic-Cretaceous, broadly N-S directed rifting between Australia and Antarctica (Miller et al., 2002 and references therein). Different regional paleo-extension directions, ranging from NW-SE (Willcox and Stagg, 1990; Willcox et al., 1992; O’Brien et al., 1994; Power et al., 2001) to N-S and NNE-SSW (Etheridge et al., 1985; Hill et al., 1994, 1995; Finlayson et al., 1996; Chantraprasert et al., 2001; Krassay et al., 2004), have been inferred for rifting of the Gippsland Basin based on the orientations of rift-related faults. The Gippsland Basin is characterised by three main sets of rift and subsequent reactivation-related faults (Fig. 1). NE-SW and ENE-WSW striking, reverse-reactivated normal faults are dominant in the western onshore part of the basin. Fault and anticline traces in the eastern 
onshore part of the basin trend roughly E-W, and normal fault traces in the eastern offshore part trend mostly WNW-ESE to NW-SE (Constantine, 2001; Power et al., 2001). Power et al. (2003) proposed that two stages of extension occurred: the first-stage NW-SE extension was followed by a second-stage NE-SW or NNE-SSW extension (Fig. 2). At a broader scale, palinspastic rift reconstructions support NNW-SSE to N-S lithospheric extension between the onset of Australian Southern Margin rifting at $\sim 160 \mathrm{Ma}$ and break-up at $\sim 83.5$ (Williams et al., 2011), with an increase in rift obliquity occurring at ca. $100 \mathrm{Ma}$ (Matthews et al., 2012; Müller et al., 2016).

It is possible that variable rift fault orientations in the Gippsland Basin are controlled by lateral or temporal changes in regional extension directions. However, the changes in orientation may instead reflect the local influence of pre-existing structures in the underlying basement. Samsu et al. (2019) suggested that NE-SW to ENE-WSW trending syn-rift faults in the Early Cretaceous cover rocks of the western onshore Gippsland Basin (Fig. 3) have orientations that are oblique to those expected from N-S or NNE-SSW directed regional extension proposed in existing literature due to the influence of an underlying anisotropic, heterogeneous basement. Similarly, the lateral change in Early Cretaceous normal fault orientations in the neighbouring Otway Basin coincides with the boundary between two rheologically different basement domains, which may have resulted in the local rotation of extension directions (Miller et al., 2002).

Rifting in the Gippsland Basin began in the Early Cretaceous (Fig. 2), first forming syndepositional normal faults in the onshore Gippsland Basin that trend NE-SW to E-W (Willcox et al., 1992) (Fig. 1). Rifting was interrupted by a period of uplift and inversion at the end of the Early Cretaceous (Dumitru et al., 1991; Duddy and Green, 1992; Foster and Gleadow, 1992; Willcox et al., 1992; Samsu et al., 2019). This event was associated with NNW-SSE oriented shortening, which reactivated NE-SW and ENE-WSW striking rift- 
related normal faults in a reverse sense and also formed NE-SW and ENE-WSW trending anticlines in the onshore part of the basin (Norvick and Smith, 2001). Rifting then resumed and continued into the Late Cretaceous, during which time E-W to NW-SE trending riftrelated faults (e.g., the Rosedale and Foster fault systems; Fig. 1) formed in the eastern onshore and offshore Gippsland Basin (Power et al., 2003). The post-rift Cenozoic history records additional tectonic episodes associated with compression and a NNW-SSE oriented maximum horizontal stress. The stress state has not changed significantly since this time, as the present-day in-situ stress is characterised by a NW-SE oriented $\left(130 \pm 20^{\circ}\right)$ maximum horizontal stress determined from borehole breakouts (Hillis and Reynolds, 2000).

$<$ Insert Figure 2 here >

\subsection{Structural descriptions of cover and basement rocks}

This paper discusses the interaction between the two basement units underneath the Gippsland Basin - the folded and faulted Paleozoic basement and a deeper NeoproterozoicCambrian basement - and the syn-rift Lower Cretaceous Strzelecki Group cover rocks that unconformably overlie the basement. The following sections provide a brief overview of the geology and structural trends within these three units.

<Insert Figure 3 here>

\subsubsection{Cretaceous cover rocks}

Rocks of the Lower Cretaceous Strzelecki Group are exposed in cliffs and wave-cut platforms along the coastline near San Remo and in the Cape Paterson area (Fig. 3). These outcrops comprise alternating layers of mud-dominated and sand-dominated siliciclastic rocks with conglomeritic or organic matter-rich interbeds, which were deposited in a fluvial setting (Constantine, 2001). Dip angles of bedding are low, varying between $6^{\circ}$ and $26^{\circ}$ (Aghaei et al., 2017). High-angle changes in the strike of bedding occur across faults, some 
of which extend seawards beyond the wavecut platforms, where they can be interpreted from bathymetry data (Samsu et al., 2019). NW-SE to NNW-SSE trending dolerite dykes of Cretaceous age crosscut the Strzelecki Group, exploiting older NW-SE and NNW-SSE striking faults and sub-vertical joints (Duddy and Green, 1992; Constantine, 2001; Samsu et al., 2019).

ENE-WSW trending faults in Cretaceous cover rocks (Fig. 3) are Early Cretaceous riftrelated faults that were reactivated during a subsequent Early Cretaceous shortening event (Samsu et al., 2019). This phase of NNW-SSE directed maximum horizontal compression was also responsible for NNW-SSE jointing at Harmers Haven (Cape Paterson area; Fig. 3). N-S to NNE-SSW trending faults crop out along the coast between Harmers Haven and Inverloch (in the Cape Paterson area) and appear as up to $20 \mathrm{~m}$ wide fracture zones in nearshore bathymetry data (Fig. 4). Similarities in their orientation and kinematics with pre-rift basement faults, such as the Waratah Fault and Selwyn Fault (Gray et al., 1999; Gardner et al., 2009; Samsu et al., 2019), suggest that they could have formed in association with reactivation of NNE-SSW trending basement fractures.

<Insert Figure 4 here>

\subsubsection{The Paleozoic basement}

The eastern onshore and offshore parts of the Gippsland Basin, which lie east of our study area, overlie the Tabberabbera, Kuark, and Mallacoota Zones of the Lachlan Orogen (VandenBerg et al., 2000) (Fig. 1). The western onshore part of the Gippsland Basin, which is the focus of this study, is underlain by Paleozoic rocks of the Melbourne Zone. The Melbourne Zone exhibits a range of Paleozoic structural trends, from NNW-SSE to NNESSW, as a result of folding and thrusting associated with E-W shortening during the Middle Devonian Tabberabberan Orogeny (VandenBerg et al., 2000). North of the Gippsland Basin, 
major faults and fold axial traces trend predominantly NNW-SSE, with the exceptions in the northernmost part of the Melbourne Zone, where E-W trending faults and fold axial traces may indicate an episode of N-S shortening that postdates the E-W shortening (VandenBerg et al., 2000).

Underneath the western onshore Gippsland Basin, a NNE-SSW structural trend can be observed in Ordovician rocks that crop out on the Mornington Peninsula and Devonian rocks that are exposed at Cape Liptrap (Keetley et al., 2001; Cayley et al., 2002; Vollgger and Cruden, 2016) (Fig. 3). Exposed Paleozoic faults trend NNE-SSW (Gray et al., 1999; Cayley et al., 2002), such as the Waratah Fault, Bell Point Fault, and Selwyn Fault (Fig. 3). The Waratah Fault, which is exposed along the southeastern side of Cape Liptrap, has been reactivated multiple times, up until the Holocene (Gardner et al., 2009). The seismically active Selwyn Fault follows the western margin of the Mornington Peninsula (Fig. 3) (Willcox et al., 1992; Cayley et al., 2002). Because of the high contrast in the magnetic characteristics of the rocks on either side of the Selwyn Fault and the length of the fault, it is interpreted that this structure links down into older faults in the Neoproterozoic-Cambrian basement that were active during the Cambrian Tyennan Orogeny (Cayley et al., 2002). The spacing between these deep crustal faults is relatively wide - for example, the Waratah Fault and Selwyn Fault are $\sim 100$ km apart.

\subsubsection{The Neoproterozoic-Cambrian basement}

The Paleozoic Melbourne Zone unconformably overlies the Neoproterozoic-Cambrian Selwyn Block (Cayley et al., 2002; McLean et al., 2010) (Fig. 1). Folds in the Melbourne Zone, which formed during the Tabberabberan Orogeny, have longer wavelengths and lower amplitudes than those in the adjacent zones, to the west and east, respectively. Therefore, it has been inferred that the underlying Selwyn Block is more rigid than the surrounding lower 
crust and that it shielded the Melbourne Zone from extensive deformation (VandenBerg et al., 2000).

The Selwyn Block comprises metasedimentary and metavolcanic rocks of Neoproterozoic-

197 Cambrian age that were accreted onto the east Gondwanaland margin during the Late Cambrian Delamerian Orogeny (Cayley, 2011). The Cambrian minimum age for regional deformation is defined by an unconformity above Selwyn Block rocks, which crop out at several locations, including at Cape Liptrap (Cayley et al., 2002; VandenBerg et al., 2006). The Selwyn Block comprises several lithological and structural units, as indicated by N-S to NE-SW trending magnetic anomalies (Moore et al., 2016). In south-central Victoria a steeply SW-dipping, NW-trending fault displaces Devonian rocks against Cambrian rocks, which has been interpreted as a Cambrian fault that underwent reactivation during the Tabberabberan Orogeny (ca. 380 Ma; Gray and Willman, 1991). The eastern boundary of the Selwyn Block and internal fabrics within the study area, inferred from potential field data and fault orientations in the overlying units (Cayley et al., 2002), trends NE-SW (Fig. 1).

\section{METHODS}

209 A multi-scale structural mapping approach was employed to identify correlations between structures in basement and cover rocks. In this study, "fractures" include shear fractures and

211 joints, all of which form when rocks fail in a brittle manner. The term "fault" is used to

212 describe a zone comprising linked segments of shear fractures when the individual shear

213 fractures cannot be recognised at the scale of observation. "Fracture zone" is used for areas of

214 intensely fractured rock, which in wavecut platforms have typically been eroded. The term

215 "joint" is used to describe a fracture that exhibits no offset along its length at the scale of 216 observation. Fractures are considered systematic when they are parallel or sub-parallel or are 217 regularly distributed, hence a fracture set consists of parallel to sub-parallel systematic 
fractures. Irregularly oriented fractures that demonstrate no obvious spatial relationship to one another are considered to be non-systematic.

220 Outcrop-scale mapping of basement structures was conducted on Melbourne Zone outcrops at Shark Stack (Cape Liptrap, see Fig. 3 for location). Although Cambrian metavolcanic rocks of the Selwyn Block are exposed nearby (Cayley et al., 2002), the highly deformed nature of the outcrop made it unsuitable for collecting structural measurements. Structures at the Shark Stack locality were interpreted from field observations, with the help of orthophotos generated from aerial photographs collected from an unmanned aerial vehicle (UAV) (Vollgger and Cruden, 2019). Previous mapping of basin-scale (>1 km-scale) faults using gravity and magnetic data (Samsu et al., 2019), help to constrain general structural trends and distinguish between pre-rift and syn-rift structures in the basement. Fractures in cover rocks in the Cape Paterson area (see Fig. 3 for location) were traced from UAV orthophotos, which facilitated rapid collection of data on thousands of fractures over a wide area at high spatial resolution. Here we introduce the workflow used for collecting fracture data and for evaluating trends in the orientation of fracture traces.

\subsection{Semi-automated fracture tracing}

UAV-derived orthophotos of outcrops enabled the collection of fracture data at five outcrop localities (Fig. 4) over a total area of $\sim 0.934 \mathrm{~km}^{2}$. These orthophotos are suitable for evaluation of fracture variability and clustering across a wide area using the areal sampling method, where fracture traces are mapped in two dimensions (2D) using aerial photographs (Wu and Pollard, 1995; Watkins et al., 2015). As the individual mapped areas were relatively large (up to $0.330 \mathrm{~km}^{2}$ ), the likelihood for sampling bias at each map locality - which can be problematic when fracture patterns change with position (Rohrbaugh et al., 2002) - could be 
reduced. For a summary of the UAV photogrammetry workflow and the parameters chosen for the UAV surveys, see Table 1 in the supporting information (cf. Dering et al., 2019).

243 Fractures at the five outcrop localities - Harmers Haven North, Harmers Haven South, Eagles

244 Nest, The Caves-Flat Rocks, and Inverloch (Fig. 4) - were interpreted using a semiautomated fracture tracing method (Fig. 5). The method, implemented as a QGIS plugin, GeoTrace (Thiele et al., 2017), uses a least-cost path algorithm on a cost function that highlights geological features. We traced fractures that were visible at one chosen scale of 1:500 (Fig. 6). We found that tracing fractures at this scale provided a good balance between maximizing the use of the high-resolution orthophotos (down to $1.94 \mathrm{~cm} /$ pixel) and limiting the amount of time required to trace all of the observable fractures (up to eight hours for one locality). Our method ensured that when we analysed the orientation of the fracture populations from different localities, we were comparing fractures that were observable at the same scale.

$<$ Insert Figure 5 here>

\subsection{Fracture orientation analysis using length-coloured rose diagrams}

257 Circular histograms, or rose diagrams, are common statistical plots for analysing the orientation distribution of fractures within a study area (e.g., Marchegiani et al., 2006; Munro and Blenkinsop, 2012; Lavenu et al., 2013; Healy et al., 2017). Unweighted rose diagrams are calculated without discrimination between fractures of different lengths. Weighted rose diagrams are typically calculated by weighting the influence of a fracture's orientation by the fracture length. An alternative to binned rose diagrams are Gaussian smoothed rose diagrams (e.g., Robin and Jowett, 1986), which are useful for accentuating trends in orientation data. 
trends, none of them show the length of the fractures that make up each trend in a rose diagram.

267 In this study, we are interested in the contribution of fractures of different lengths to fracture

268 orientation trends within each outcrop area. Our approach is concerned with whether fractures of different lengths develop different orientations preferentially, therefore testing for scale-dependence. Fracture traces that are relatively long are often straight, continuous joints that have not been offset by subsequent shear fractures. Alternatively, they can represent larger faults, where individual shear fracture segments cannot be recognised at the scale of observation, either due to the close spacing between segment tips or weathering along the fracture. Shorter fracture traces mostly represent joints, shear fractures, or non-systematic fractures.

Here we present a new technique for characterizing the trends in a fracture population, where the distribution of fracture length is plotted on an unweighted rose diagram to produce "length-coloured rose diagrams". These rose diagrams allow for a more comprehensive analysis of the fracture network, showing whether each peak orientation is associated with relatively "short" or "long" fracture traces. The petals of the rose diagram are subdivided into coloured segments that represent the percentage contribution of fractures within each length bin. This method has been implemented in the GeoTrace plugin for QGIS (Thiele et al., 2017; https://github.com/lachlangrose/GeoTrace). Fracture orientations were compared between the five different outcrop localities (Fig. 4 and 5). For each locality, all of the fractures that were traced at a scale (or 'zoom') of 1:500 were treated as one population, resulting in one rose 286 diagram per locality.

\subsection{Fracture orientation analysis using gridded rose diagrams}


288 A second analysis was performed to assess the heterogeneity of fracture patterns within individual outcrop localities, as there is usually significant variation in fracture density or orientations even within a small area. For the Harmers Haven North locality (see Fig. 4 for location), fractures were traced manually at a scale of 1:500. Grid tiles with $100 \mathrm{~m}$ by $100 \mathrm{~m}$ dimensions were overlain onto the fracture trace map, and a length-weighted binned rose diagram (with $10^{\circ}$-wide bins) was generated for the fracture trace segments in each grid tile, resulting in one rose diagram per grid tile (Fig. 7). Grid tiles that contained less than 30 fracture trace segments were excluded from the analysis. This technique is implemented in the Line Direction Histogram plugin (Tveite, 2015) for QGIS. This method allowed us to test the consistency of fracture orientations throughout an outcrop. It also assisted in determining whether clustering or anomalous fracture patterns in a given locality are associated with changes in lithology, structural style, or other factors.

\section{RESULTS}

\subsection{Structural characteristics of basement rocks (Cape Liptrap)}

The Shark Stack outcrop is located near the southwestern tip of Cape Liptrap (Fig. 8). Here, tightly folded turbidites of the Devonian Liptrap Formation are exposed on wavecut platforms and steep, SSW-facing cliffs (Fig. 9 and 10). The rocks comprise steeply dipping, alternating beds of sandstone and mudstone, and they exhibit a first-order NNE-SSW structural trend in map view (Fig. 8c). The sequence of ductile and brittle deformation inferred for the Shark Stack locality is summarised in Table 1, interpreted using observations acquired from both field and UAV-based mapping of structures. 
312 The strike of bedding in the fold limbs is predominantly NNE-SSW, with beds dipping

313 steeply to sub-vertically towards the ESE and WNW (Fig. 9d). The fold axis calculated from

314 bedding measurements (from across the entire outcrop) trends $198^{\circ}$ and plunges $20^{\circ}$, which represents the fold axis of first-generation F1 folds at this locality. This fold axis is consistent with the F1 fold axis reported for the southern part of Fold Stack (201/11; Vollgger and Cruden, 2016), which is located approximately 400 m northeast of Shark Stack (Fig. 8b). A steeply ESE-dipping to sub-vertical, axial planar cleavage is consistent with the bedding measurements and fold axis, suggesting that local shortening was WNW-ESE. We interpret the F1 folds in the area to be related to $\sim \mathrm{E}-\mathrm{W}$ shortening associated with the Devonian Tabberabberan Orogeny (385 - 380 Ma; VandenBerg et al., 2000). Reverse faults with a low strike angle to bedding offset sandstone beds, while associated strain is accommodated by ductile deformation of the mudstone layers.

The Shark Stack outcrop contains N-S trending zones of intensely folded beds (Fig. 10). In map view, these structures appear to be either reverse kink bands or disharmonic folds (Fig. 10a), though in cross section (along subvertical cliffs) they appear exclusively as disharmonic folds (Fig.10b). Kink band formation in some zones has progressed to chevron folding (Fig. 10a). Similar "kink folds" have been observed in shale-rich outcrops at the southernmost tip of Cape Liptrap, $~ 800 \mathrm{~m}$ southeast of Shark Stack. Kink fold hinges plunge mostly to the south (Fig. 9e), consistent with N-S trending axial traces mapped on the 2D dataset (Fig. 10a). As the kink folds' axial traces are oblique to the NNE-SSW trending F1 fold axial traces, we suggest that these F2 kink folds formed during a separate D2 folding event. 
F2 kink folds may have formed due to NNE-SSW oriented shortening, which was directed sub-parallel to the strike of bedding. This interpretation is based on analogue experiments, field examples, and mechanical experiments of kink bands in anisotropic media, which suggest that reverse kink bands result from local shortening parallel to the anisotropy (e.g., Cobbold et al., 1971; Stubley, 1989; Kapp et al., 2016). The dextral sense of shear required to create the observed kink fold geometry, as well as the orientation of the folds, is also consistent with NNE-SSW oriented shortening. Field evidence for N-S to NNE-SSW shortening - including E-W trending folds, north-dipping reverse faults, and steeply dipping, E-W striking axial planar cleavage - at a later stage of the Tabberabberan Orogeny (following E-S shortening) has also been found in the northern part of the Melbourne Zone (Gray and Mortimer, 1996; Wilson et al., 2017).

ENE-WSW trending dextral shear fractures and a larger fracture zone of the same orientation (Fig. 8c) is attributed to a D3 brittle deformation event. Like the ENE-WSW trending fracture set at Fold Stack (Vollgger and Cruden, 2016), this set is parallel to Early Cretaceous riftrelated normal faults within the Lower Cretaceous Strzelecki Group (Samsu et al., 2019). They are the only structures at Shark Stack that can be associated with Early Cretaceous Gippsland Basin rifting.

A D4 deformation event is associated with a NW-SE trending kink band zone that extends across the middle and along the length of the entire Shark Stack outcrop, overprinting F2 kink bands (Fig. 8c and 10). In this <3.3 m wide zone, the local sense of shear is dextral, and the kinks offset the sandstone and mudstone layers laterally by $<1 \mathrm{~m}$. Smaller, less developed kink bands of the same orientation are also present. A NNW-SSE trending set of sinistral fractures occurs in the northwest section of the outcrop (Fig. 8c). The acute bisector between 
the F4 kink bands and the NNW-SSE fractures is $\sim 30^{\circ}$. Based on the orientation and kinematics of the F4 kink bands and the NNW-SSE trending fracture set, we interpret them as conjugate structures that formed during a phase of NNW-SSE directed D4 shortening. The relative timing of D3 fractures and D4 kinks is ambiguous - the large ENE-WSW trending fracture zone potentially offsets NW-SE trending kink bands in the orthophoto (Fig. 8c), but the amount of weathering in this part of the outcrop makes it difficult to confirm this. As the two sets are orthogonal to each other and both exhibit a dextral sense of movement, they cannot have formed coevally.

Most of the NW-SE trending structures at Shark Stack that were mapped using the UAV orthophoto are short F4 kink bands (<10 $\mathrm{m}$ in length) (Fig. 11). Longer fractures $(>10 \mathrm{~m})$ are associated with NNW-SSE and ENE-WSW trending fracture sets. These fractures are relatively young D3 and D4 structures compared to pre-rift D1 and D2 structures and show high lateral continuity because they have not been overprinted by younger structures.

\subsection{The orientation of fractures in cover rocks (Cape Paterson area)}

Fracture orientation trends in the Strzelecki Group cover rocks in the Cape Paterson area (see Fig. 3 for location) are presented as rose diagrams (Fig. 4 and 5) and summarised in Table 2. Here we describe fracture orientations at five outcrop localities - Harmers Haven North, Harmers Haven South, Eagles Nest, the Caves - Flat Rocks, and Inverloch - and use peaks in the data to classify fracture traces into fracture sets. We also use overprinting relationships between fracture traces in the UAV orthophotos and field observations to identify the type of fractures that make up each fracture set. 

fracture set comprises linear, systematic joints that are parallel to - and are potentially exploited by - NNW-SSE trending mafic dykes. We observe two other peaks in the data for this locality: WNW-ESE $\left(280-295^{\circ}\right)$ and E-W $\left(080-100^{\circ}\right)$, which correspond to shear fractures. These two sets are more prevalent in the central part of the outcrop, while the NNW-SSE trending set is more dominant in the western and eastern parts of the outcrop. The longer $(>30 \mathrm{~m})$ fracture traces at this locality are faults across which the strike of bedding changes significantly. A more detailed discussion of the spatial variability of fracture trends at Harmers Haven North (Fig. 7) is presented below.

At Harmers Haven South, one wide peak in the rose diagram is present, trending NNW-SSE $\left(325-345^{\circ}\right)$ (Fig. 5d). The NNW-SSE fracture set consists mostly of joints, some of which are exploited by NNW-SSE trending mafic dykes at the northern end of the outcrop. Faults trend NW-SE and some of them are also exploited by NW-SE trending mafic dykes.

The Eagles Nest locality was split into a southern and northern area (Fig. 5b). The rose diagram of fracture traces in both areas combined show a dominant NNW-SSE $\left(325-345^{\circ}\right)$ peak. The second most dominant trend is represented by a wide peak, trending ENE-WSW $\left(065-080^{\circ}\right)$ and E-W $\left(080-095^{\circ}\right)$. In the southern area, NNW-SSE and ENE-WSW trending systematic fracture sets, which are mutually crosscutting, are present near the Eagles Nest pinnacle. The ENE-WSW trending normal fault slightly north of the pinnacle is associated with Early Cretaceous rifting. A NE-SW trending fracture set is confined to a small area west of the pinnacle. In the northern area, a large N-S trending fracture zone bounds the Eagles Nest locality to the east. The N-S trending fault truncates an ENE-WSW trending fault and the NNW-SSE fracture set to the west. The significant rotation of sedimentary beds across this fault and the syn-sedimentary nature of ENE-WSW trending normal faults in the area (Samsu et al., 2019) suggests that the N-S fault postdates ENE-WSW normal faulting. 
At the Caves - Flat Rocks, the main peak in the rose diagram corresponds to NNW-SSE

407

408 $\left(320-345^{\circ}\right)$ trending shear fractures (Fig. 5e). The second-most dominant peak is associated with ENE-WSW $\left(065-085^{\circ}\right)$ trending fractures, some of which are normal faults associated with Early Cretaceous rifting. A third, less dominant NNE-SSW $\left(010-020^{\circ}\right)$ trend is made up of shear fractures. ENE-WSW trending faults are offset by NNW-SSE and NNE-SSW trending shear fractures, which may explain why this fracture set has the highest percentage of shorter $(<10 \mathrm{~m})$ fractures relative to their frequency. The Inverloch locality is populated by fractures that are shorter than $20 \mathrm{~m}$ (Fig. 5c). One sharp E-W trending peak $\left(085-095^{\circ}\right)$ and another sub-population of WNW-ESE to NNW-SSE $\left(290-345^{\circ}\right)$ trending fractures are represented in the rose diagram.

A common occurrence among the five described localities is the presence of a NNW-SSE trending fracture set, which mostly consists of sub-vertical joints. This joint set is interpreted to be a pervasive, regional outcrop-scale joint set that reflects Early Cretaceous shortening (Samsu et al., 2019), which postdates Early Cretaceous syn-rift normal ENE-WSW faulting and predates the Aptian intrusion of NW-SE and NNW-SSE trending mafic dykes in the study area. The formation of this joint set could also be coeval with reverse reactivation of the optimally oriented, aforementioned ENE-WSW trending normal faults, which agrees with an interpretation by Power et al. (2003) of similarly orientated compressional structures in the offshore Gippsland Basin.

\subsubsection{Variability of fracture orientations within the Harmers Haven North locality}

The Harmers Haven North outcrop was subdivided into three domains based on the main fracture orientations (Table 2; Fig. 7). The western section of the outcrop (Domain A) exhibits a dominant NNW-SSE trending fracture set. Field observations confirm that this set is made up of joints, similar to the NNW-SSE trending fracture set at Harmers Haven South. 
Domain A also contains a single NNW-SSE trending dyke that is parallel with the main joint set. A less prominent E-W trending fracture set is present in Domain A. The middle section of the outcrop (Domain B) exhibits a dense network of approximately E-W trending, nonsystematic shear fractures. Three NNE-SSW trending shear fractures in Domain B (represented by thick red lines in Fig. 7) correspond to km-scale faults interpreted from nearshore bathymetry (Fig. 4). The eastern section of the outcrop (Domain C) exhibits the same NNW-SSE joint set as observed in Domain A, although fractures of other orientations are also present.

\subsubsection{Curved fractures at the Eagles Nest locality}

The most dominant fracture set at Eagles Nest is the NNW-SSE trending set of up to $50 \mathrm{~m}$ long fractures (Fig. 12). NNW-SSE trending fractures in the northern area curve eastwards into the N-S trending fracture zone. There is no evidence of shear along these NNW-SSE trending fractures, so they can be interpreted as joints, like the NNW-SSE trending joints at Harmers Haven North and Harmers Haven South (Table 2). The curved NNW-SSE joints at Eagles Nest are comparable with joints that "veer" from linearity (Cruikshank and Aydin, 1995) as they propagate into a changing stress field, which may result from stress perturbations near pre-existing structures. Photoelastic experiments on analogue materials (e.g., de Joussineau et al., 2003) demonstrate the deviation of stress trajectories near preexisting defects (analogous to faults in rocks) under a biaxial compressive load. Welch et al. (2014) discuss the development of local stress anomalies near tips, bends and splays in larger faults. At Eagles Nest, veering of the NNW-SSE joints would have resulted from the divergence of local maximum principal stress trajectories from the regional shortening, which was due to local stress perturbations around the large N-S trending fracture zone. 


\subsection{Rift faults oblique to basement structures and the regional extension direction}

455

456

457

In the western onshore Gippsland Basin, NNE-SSW striking faults in the NeoproterozoicCambrian Selwyn Block basement were reactivated during Devonian deformation of the shallower Melbourne Zone basement, forming the Waratah and Selwyn faults. In contrast to these contractional structures, Cretaceous normal syn-rift faults in the study area trend NESW to ENE-WSW, oblique to NNE-SSW striking basement faults and foliation. These synrift faults are also oblique to their expected E-W orientation, given the E-W orientation of syn-rift faults in the eastern portion of the Gippsland Basin and the N-S to NNE-SSW regional extension inferred in the literature (Etheridge et al., 1985; Hill et al., 1994, 1995; Finlayson et al., 1996; Chantraprasert et al., 2001; Krassay et al., 2004).

Reactivation of basement structures ought to have resulted in NNE-SSW trending normal faults that are parallel to pre-existing planar basement weaknesses (cf.. Holdsworth et al., 1997; Kirkpatrick et al., 2013; Phillips et al., 2016). Hodge et al. (2018) have shown, using field observations from the Malawi Rift System in East Africa, that faults can form oblique to the reactivated basement foliation. However, these foliation-oblique faults exhibit variable strike and form links between en échelon, foliation-parallel fault scarps. In our western onshore Gippsland Basin case study, the syn-rift faults are parallel to each other, forming a systematic NE-SW to ENE-WSW trending set. We therefore argue that a more widespread rotation of the local extension direction (caused by the underlying pervasive basement anisotropy) contributed to the obliquity of these faults as opposed to localised strain or stress rotations along a single structure. These observations suggest that a mechanism other than reactivation may be responsible for inheritance-influenced, syn-rift normal faulting (Fig. $13 b)$. 
Existing research on inheritance in rift basins largely focuses on reactivation (e.g., Whipp et al., 2014; Phillips et al., 2016; Fazlikhani et al., 2017; Collanega et al., 2019; Heilman et al., 2019). We suggest that a second, poorly understood mechanism of structural inheritance involves a rotation or perturbation of the local extension direction above an anisotropic basement unit with a structural trend that is oblique to the rifting direction. Our observations are comparable with the results of field studies from north-western Scotland (Wilson et al., 2010) and the East African rift system (Morley, 2010), where fracture orientations vary between areas that have different basement domains. Lateral changes in fracture orientation act as evidence for localised rotations of strain (Philippon et al., 2015; Williams et al., 2019), which may reflect local perturbations or re-orientation of the far-field stress.

\subsection{The influence of multiple levels of basement on cover faults}

Two depth levels of basement beneath the western onshore Gippsland Basin study area likely had an impact on basin formation (Fig. 1). Both levels of basement were subjected to multiple shortening events prior to Early Cretaceous rifting and opening of the Gippsland Basin, resulting in a first-order NNE-SSW structural trend (Gray et al., 1999; Cayley et al., 2002; McLean et al., 2010; Moore et al., 2016) that is oblique to subsequent Cretaceous riftrelated structures. NNE-SSW trending faults in the Melbourne Zone formed as a result of roughly E-W shortening during the Devonian Tabberabberan Orogeny. Some of these faults, such as the Waratah and Selwyn faults, extend into the underlying Selwyn Block basement, so it has been suggested that reactivation of Selwyn Block faults exerted some control on Devonian deformation in the Melbourne Zone basement (Cayley, 2011) (A in Fig. 13a).

Based on field observations of NNE-SSW striking D1 structures at Shark Stack and Fold Stack (Vollgger and Cruden, 2016) (Cape Liptrap; Fig. 9) and similarly trending faults and formlines in Paleozoic rocks on the Mornington Peninsula ( $100 \mathrm{~km}$ northwest of Cape 
Liptrap; Fig. 3) (Cayley et al., 2002; McLean et al., 2010), we infer that the Melbourne Zone basement beneath our mapped Cretaceous cover outcrops (Cape Paterson area; Fig. 3) exhibits a penetrative NNE-SSW trending anisotropy. The mechanical anisotropy created by alternating mudstone and sandstone units has the potential to locally perturb the regional stress field. Alternatively, relatively weak mudstone layers between competent sandstone layers may be prone to re-shearing when the crust is subject to later extension or compression. This anisotropy should have exerted a greater influence on regional faulting patterns in the cover compared to less pervasive, more localised fractures (B in Fig. 13a).

The postulated eastern boundary of the Selwyn Block (and the overlying Melbourne Zone) was partly defined by a change from NE-SW and ENE-WSW trending faults in the western onshore part of the Gippsland Basin to E-W trending faults in the eastern onshore and offshore parts (Cayley et al., 2002) (Fig. 1). The lower crustal Selwyn Block is inferred to be more rigid than the surrounding lower crust (Cayley et al., 2002; Teasdale et al., 2004), so that the Selwyn Block boundary separates an anomalously strong lower crustal block from the "normal" lower crust. The strength contrast between the Selwyn Block and the adjacent, weaker, lower crust could be an additional source of local strain re-orientation that contributed to the extension-oblique orientation of the rift faults in the cover ( $\mathrm{C}$ in Fig. 13a).

\section{$519 \quad 5.3 \quad$ Structural inheritance is not scale-invariant}

520 Multi-scale mapping of fracture traces allowed comparison between: 1) the orientations of outcrop-scale basement and cover structures, and 2) the orientations of basin-scale (>1 kmscale) fractures and outcrop-scale (meters to tens of meters-scale) fractures. By comparing D3 and D4 basement structures with cover fractures, we observed that a single tectonic event can be reflected by different fracture trends in basement and cover rocks, likely due to differences in the mechanical anisotropy. Outcrop-scale cover fractures in our study area 
have trends that are different to outcrop-scale basement fractures, with the exception of the ENE-WSW trending fracture set (Fig. 3 and 4). Syn-rift normal faults exhibit the same ENEWSW trend at both basin scale and outcrop scale (Fig. 14a).

The trends of outcrop-scale fractures that formed during NNW-SSE shortening are different from the trends of basin-scale (>1 km-long) fractures (Fig. 14b); joints formed at the small scale, but reverse reactivation of normal faults occurred at the large scale. The persistent NNW-SSE peak in the outcrop-scale fracture data highlights the abundance and pervasiveness of a NNW-SSE trending subvertical joint set in the Strzelecki Group cover rocks across the entire study area. Samsu et al. (2019) have discussed the formation of this joint set under NNW-SSE directed maximum horizontal stress, coeval with a conjugate set of NNW-SSE and N-S to NNE-SSW trending strike-slip faults, and reactivation of optimally oriented NNE-SSW striking basement faults in a strike-slip sense, which explains the NNESSW fracture trend in the rose diagram for $>1 \mathrm{~km}$-scale faults (Fig. 14b). This event may have coincided with Early Cretaceous (Aptian) basin uplift and the reverse reactivation of ENE-WSW rift faults during basin inversion (Holdgate et al., 2003; Power et al., 2003).

Aptian contractional structures are associated with NNW-SSE directed maximum horizontal stress and reflect different stress states. The first group of structures, comprising NNW-SSE trending joints, conjugate strike-slip faults, and strike-slip reactivated NNE-SSW striking basement faults, would have required a horizontal least principal stress $\left(\sigma_{3}\right)$. The second group, comprising ENE-WSW striking normal faults that have been reactivated in a reverse sense, would have required a vertical $\sigma_{3}$. By drawing comparisons with Van Noten et al.

548 (2012) on the evolution of the 3D stress field during tectonic inversion, we infer that the two groups of structures were active at different stages of basin inversion. The first group could 
have been active during an earlier stage of basin inversion, and the second group is associated with a later stage of inversion after $\sigma_{3}$ switched from horizontal to vertical (and the opposite occurred for the intermediate stress, $\sigma_{2}$ ). It is therefore possible that temporal changes in the stress field contribute to the scale-dependent nature of structural inheritance, though this relationship requires further exploration.

At outcrop scale, NNW-SSE trending joints behave differently near large faults that either pre-date or are coeval with joint formation. At Eagles Nest, the joints veer into perpendicularity with a large N-S trending fracture zone that may have locally perturbed farfield stress trajectories (Fig. 12). This joint set is absent adjacent to NNE-SSW trending faults at Harmers Haven North. Our results imply that outcrop-scale fractures (such as joints) may be faithful recorders of the far-field stress when not affected by adjacent larger faults, which serve to alter the local stress field.

\section{CONCLUSIONS}

Pre-existing basement structures exert significant control on the orientation and distribution of fractures in the sedimentary cover rocks of a rift basin. However, this basement influence manifests itself differently at different scales. Inheritance does not always result in cover fractures that are parallel to basement structures, which is expected with basement reactivation. In the western onshore Gippsland Basin, both basin-scale and outcrop-scale synrift faults are oblique to the basement trends as well as their expected orientation based on the inferred regional paleo-extension direction, suggesting that stresses above the basement structures were perturbed such the extension direction was locally rotated, and faults in the cover rocks became misaligned to both their expected orientation and the basement anisotropy. This finding should motivate us to explore and model the mechanisms of 
structural inheritance, other than reactivation, through additional field-based studies as well as analogue and numerical experiments.

When attempting to understand the influence of structural inheritance on deformation in a rift basin, it is important to consider not just the basement that directly underlies the sedimentary cover, but older, deeper basement units as well. As multiple levels of basement are often present, it is challenging to distinguish the relative contributions of pre-existing structures from each basement unit. In our study area, widely spaced faults in the deeper Neoproterozoic-Cambrian Selwyn Block basement were reactivated during Devonian deformation of the shallower Melbourne Zone basement. Because these faults appear to have been reactivated again during subsequent, post-rift deformation of the cover rocks, it is evident the Selwyn Block basement faults influence structural geometry over multiple tectonic events, albeit at a large scale. The pervasive anisotropy of the Melbourne Zone may have exerted a greater control than the Selwyn Block faults on more closely-spaced fractures (i.e., Cretaceous rift-related normal faults). This example shows the importance of mapping structures in all of the basement units, at multiple scales, to explore the possibility of different wavelengths of basement influence.

Our findings demonstrate that in basins influenced by structural inheritance, fracture patterns are not scale-invariant. A proper understanding of the structural architecture can only be achieved by analysing data that span multiple scales. This observation is relevant when we try to understand and predict the distribution and orientation of fractures - at regional, basin, and reservoir-scale - in order to model fluid transport in the crust. This study also highlights the importance of mapping fractures in outcrop analogues of naturally fractured reservoirs. 
We thank Sam Thiele, Megan Withers, and Jonas Köpping for their assistance with data collection. Åke Fagereng and an anonymous reviewer are thanked for their constructive reviews. Fieldwork was partly funded by an AAPG Grants-in-Aid Award awarded to AS. AS and SAV were supported by a Monash University Faculty of Science Dean's International Postgraduate Research Scholarship.

\section{DATA AVAILABILITY}

The basemap used for structural mapping at Shark Stack (Cape Liptrap) is available at $10 \mathrm{~cm}$ resolution from https://doi.org/10.26180/5c653193efa25 (Vollgger and Cruden, 2019). The datasets used for fracture mapping at Harmers Haven North, Harmers Haven South, Eagles Nest, the Caves-Flat Rocks, and Inverloch are available from https://doi.org/10.26180/5cdcad0a73fe0 (Samsu et al., 2019).

\section{REFERENCES}

Aghaei, H., Hall, M., Wagstaff, B., Tait, A., 2017. Stratigraphic reconstruction of the Strzelecki Group outcrops in west Gippsland: new data on the present-day thickness and amount of erosion. Australian Journal of Earth Sciences 64, 251-264. https://doi.org/10.1080/08120099.2016.1278033

Bourne, S.J., Willemse, E.J.M., 2001. Elastic stress control on the pattern of tensile fracturing around a small fault network at Nash Point, UK. Journal of Structural Geology 23, 1753-1770. https://doi.org/https://doi.org/10.1016/S0191-8141(01)00027-X

Byerlee, J., 1978. Friction of rocks. Pure and Applied Geophysics 116, 615-626. https://doi.org/10.1007/BF00876528

Cayley, R.A., 2011. Exotic crustal block accretion to the eastern Gondwanaland margin in the Late Cambrian-Tasmania, the Selwyn Block, and implications for the Cambrian-Silurian 
evolution of the Ross, Delamerian, and Lachlan orogens. Gondwana Research 19, 628649. https://doi.org/10.1016/j.gr.2010.11.013

621

622

623

624

625

626

627

628

629

630

631

632

633

634

635

636

637

638

639

640

641

Cayley, R.A., Taylor, D.H., VandenBerg, A.H.M., Moore, D.H., 2002. Proterozoic - Early Palaeozoic rocks and the Tyennan Orogeny in central Victoria: The Selwyn Block and its tectonic implications. Australian Journal of Earth Sciences 49, 225-254. https://doi.org/10.1046/j.1440-0952.2002.00921.x

Chantraprasert, S., McClay, K.R., Elders, C., 2001. 3D Rift Fault Systems of the Western Otway Basin, SE Australia. In: Hill, K.C., Bernecker, T. (Eds.), Eastern Australasian Basins Symposium. Petroleum Exploration Society of Australia, Melbourne, 435-446.

Cobbold, P.R., Cosgrove, J.W., Summers, J.M., 1971. Development of internal structures in deformed anisotropic rocks. Tectonophysics 12, 23-53. https://doi.org/10.1016/00401951(71)90065-5

Collanega, L., Jackson, C.A., Bell, R.E., Coleman, A.J., Lenhart, A., Breda, A., 2019. Normal fault growth influenced by basement fabrics: the importance of preferential nucleation from pre-existing structures. Basin Research in press. https://doi.org/10.1111/bre.12327

Constantine, A., 2001. Sedimentology, Stratigraphy and Palaeoenvironment of the Upper Jurassic-Lower Cretaceous Non-Marine Strzelecki Group, Gippsland Basin, Southeastern Australia. Monash University. PhD Thesis.

Corti, G., van Wijk, J., Cloetingh, S., Morley, C.K., 2007. Tectonic inheritance and continental rift architecture: Numerical and analogue models of the East African Rift system. Tectonics 26, 1-13. https://doi.org/10.1029/2006TC002086

Cruikshank, K.M., Aydin, A., 1995. Unweaving the joints in Entrada Sandstone, Arches 
de Joussineau, G., Petit, J.P., Gauthier, B.D.M., 2003. Photoelastic and numerical investigation of stress distributions around fault models under biaxial compressive loading conditions. Tectonophysics 363, 19-43. https://doi.org/10.1016/S0040-

Dering, G.M., Micklethwaite, S., Thiele, S.T., Vollgger, S.A., Cruden, A.R., 2019. Review of drones, photogrammetry and emerging sensor technology for the study of dykes: Best practises and future potential. Journal of Volcanology and Geothermal Research. https://doi.org/10.1016/j.jvolgeores.2019.01.018

Duddy, I.R., Green, P.F., 1992. Tectonic development of the Gippsland Basin and environs: identification of key episodes using Apatite Fission Track Analysis (AFTA). Gippsland Basin Symposium 22-23 June 1992. Melbourne, 111-120.

Dumitru, T.A., Hill, K.C., Coyle, D.A., Duddy, I.R., Foster, D.A., Gleadow, A.J.W., Green, P.F., Kohn, B.P., Laslett, G.M., O’Sullivan, P.B., 1991. Fission track thermochronology: Application to continental rifting of south-eastern Australia. The APEA Journal 31, $131-142$.

Etheridge, M.A., Branson, J.C., Stuart-Smith, P.G., 1985. Extensional basin-forming structures in Bass Strait and their importance for hydrocarbon exploration. The APEA Journal 25, 344-361.

Fazlikhani, H., Fossen, H., Gawthorpe, R.L., Faleide, J.I., Bell, R.E., 2017. Basement structure and its influence on the structural configuration of the northern North Sea rift. Tectonics 36, 1151-1177. https://doi.org/10.1002/2017TC004514 
665

666

667

668

669

670

671

672

673

674

675

676

677

678

679

680

681

682

683

684

685

686

687

688

Finlayson, D.M., Johnstone, D.W., Owen, A.J., Wake-Dyster, K.D., 1996. Deep seismic images and the tectonic framework of early rifting in the Otway Basin, Australian southern margin. Tectonophysics 264, 137-152. https://doi.org/10.1016/S00401951(96)00123-0

Foster, D.A., Gleadow, A.J.W., 1992. Reactivated tectonic boundaries and implications for the reconstruction of southeastern Australia and northern Victoria Land, Antarctica. Geology 20, 267-270. https://doi.org/10.1130/00917613(1992)020<0267:RTBAIF>2.3.CO;2

Gardner, T., Webb, J., Pezzia, C., Amborn, T., Tunnell, R., Flanagan, S., Merritts, D., Marshall, J., Fabel, D., Cupper, M.L., 2009. Episodic intraplate deformation of stable continental margins: evidence from Late Neogene and Quaternary marine terraces, Cape Liptrap, Southeastern Australia. Quaternary Science Reviews 28, 39-53. https://doi.org/10.1016/j.quascirev.2008.10.004

Gray, D.R., Janssen, C., Vapnik, Y., 1999. Deformation character and palaeo-fluid flow across a wrench fault within a Palaeozoic subduction-accretion system: Waratah Fault Zone, southeastern Australia. Journal of Structural Geology 21, 191-214. https://doi.org/10.1016/S0191-8141(98)00115-1

Gray, D.R., Mortimer, L., 1996. Implications of overprinting deformations and fold interference patterns in the Melbourne Zone, Lachlan Fold Belt. Australian Journal of Earth Sciences 43, 103-114. https://doi.org/10.1080/08120099608728240

Gray, D.R., Willman, C.E., 1991. Thrust-related strain gradients and thrusting mechanisms in a chevron-folded sequence, southeastern Australia. Journal of Structural Geology 13, 691-710. https://doi.org/10.1016/0191-8141(91)90031-D

Healy, D., Rizzo, R.E., Cornwell, D.G., Farrell, N.J.C., Watkins, H., Timms, N.E., Gomez- 

Rivas, E., Smith, M., 2017. FracPaQ: A MATLAB ${ }^{\mathrm{TM}}$ toolbox for the quantification of fracture patterns. Journal of Structural Geology 95, 1-16. https://doi.org/10.1016/j.jsg.2016.12.003

Heilman, E., Kolawole, F., Atekwana, E.A., Mayle, M., 2019. Controls of Basement Fabric on the Linkage of Rift Segments. Tectonics. https://doi.org/10.1029/2018TC005362

Henza, A.A., Withjack, M.O., Schlische, R.W., 2011. How do the properties of a pre-existing normal-fault population influence fault development during a subsequent phase of extension? Journal of Structural Geology 33, 1312-1324. https://doi.org/10.1016/j.jsg.2011.06.010

Heron, P.J., Peace, A.L., McCaffrey, K.J.W., Welford, J.K., Wilson, R., Hunen, J., Pysklywec, R.N., 2019. Segmentation of Rifts Through Structural Inheritance: Creation of the Davis Strait. Tectonics 38, 2411-2430. https://doi.org/10.1029/2019TC005578

Hill, K.A., Cooper, G.T., Richardson, M.J., Lavin, C.J., 1994. Structural framework of the Eastern Otway basin: inversion and interaction between two major structural provinces., Exploration Geophysics. https://doi.org/10.1071/EG994079

Hill, K.C., Hill, K.A., Cooper, G.T., O’Sullivan, A.J., O’Sullivan, P.B., Richardson, M.J., 1995. Inversion around the Bass Basin, SE Australia. Geological Society, London, Special Publications 88, 525-547. https://doi.org/10.1144/GSL.SP.1995.088.01.27

Hillis, R.R., Reynolds, S.D., 2000. The Australian Stress Map. Journal of the Geological Society 157, 915-921. https://doi.org/10.1144/jgs.157.5.915

Hodge, M., Fagereng, Å., Biggs, J., Mdala, H., 2018. Controls on Early-Rift Geometry: New Perspectives From the Bilila-Mtakataka Fault, Malawi. Geophysical Research Letters 45, 3896-3905. https://doi.org/10.1029/2018GL077343 
Holdgate, G.R., Rodriquez, C., Johnstone, E.M., Wallace, M.W., Gallagher, S.J., 2003. The Gippsland Basin Top Latrobe Unconformity and its expression in other Southeast Australia basins. The APPEA Journal 43, 149-173.

Holdsworth, R.E., Butler, C.A., Roberts, A.M., 1997. The recognition of reactivation during continental deformation. Journal of the Geological Society 154, 73-78. https://doi.org/10.1144/gsjgs.154.1.0073

Holdsworth, R.E., Stewart, M., Imber, J., Strachan, R.A., 2001. The structure and rheological evolution of reactivated continental fault zones: a review and case study. Geological Society, London, Special Publications 184, 115-137. https://doi.org/10.1144/GSL.SP.2001.184.01.07

Kapp, M.W., Hohenwarter, A., Wurster, S., Yang, B., Pippan, R., 2016. Anisotropic deformation characteristics of an ultrafine- and nanolamellar pearlitic steel. Acta Materialia 106, 239-248. https://doi.org/10.1016/j.actamat.2015.12.037

Keetley, J.T., Hill, K.C., Nguyen, C., 2001. Mesoscopic fold and thrust structures at Cape Liptrap, Victoria, Australia; a PNG analogue? In: Hill, K.C., Bernecker, T. (Eds.), Eastern Australasian Basins Symposium. Petroleum Exploration Society of Australia, Melbourne, 25-28.

Kirkpatrick, J.D., Bezerra, F.H.R., Shipton, Z.K., Do Nascimento, A.F., Pytharouli, S.I., Lunn, R.J., Soden, A.M., 2013. Scale-dependent influence of pre-existing basement shear zones on rift faulting: a case study from NE Brazil. Journal of the Geological Society 170, 237-247. https://doi.org/10.1144/jgs2012-043

Krassay, A.A., Cathro, D.L., Ryan, D.J., 2004. A regional tectonostratigraphic framework for the Otway Basin. In: Boult, P.J., Johns, D.R., Lang, S.C. (Eds.), Eastern Australasian Basins Symposium II. Petroleum Exploration Society of Australia, Adelaide, 97-116. 
Lavenu, A.P.C., Lamarche, J., Gallois, A., Gauthier, B.D.M., 2013. Tectonic versus diagenetic origin of fractures in a naturally fractured carbonate reservoir analog (Nerthe anticline, southeastern France). AAPG Bulletin 97, 2207-2232. https://doi.org/10.1306/04041312225

Maerten, L., Gillespie, P., Pollard, D.D., 2002. Effects of local stress perturbation on secondary fault development. Journal of Structural Geology 24, 145-153. https://doi.org/10.1016/S0191-8141(01)00054-2

Manatschal, G., Lavier, L., Chenin, P., 2015. The role of inheritance in structuring hyperextended rift systems: Some considerations based on observations and numerical modeling. Gondwana Research 27, 140-164. https://doi.org/10.1016/j.gr.2014.08.006

Marchegiani, L., Van Dijk, J.P., Gillespie, P. a, Tondi, E., Cello, G., 2006. Scaling properties of the dimensional and spatial characteristics of fault and fracture systems in the Majella Mountain, central Italy. Geological Society Special Publication 261, 113-131. https://doi.org/10.1144/GSL.SP.2006.261.01.09

Matthews, K.J., Seton, M., Müller, R.D., 2012. A global-scale plate reorganization event at 105-100 Ma. Earth and Planetary Science Letters 355-356, 283-298. https://doi.org/10.1016/j.eps1.2012.08.023

McCaffrey, K.J.W., 1997. Controls on reactivation of a major fault zone: the Fair Head-Clew Bay line in Ireland. Journal of the Geological Society 154, 129-133. https://doi.org/10.1144/gsjgs.154.1.0129

McLean, M.A., Morand, V.J., Cayley, R.A., 2010. Gravity and magnetic modelling of crustal structure in central Victoria: what lies under the Melbourne Zone? Australian Journal of Earth Sciences 57, 153-173. https://doi.org/10.1080/08120090903416245 
Miller, J.M.L., Norvick, M.S., Wilson, C.J.L., 2002. Basement controls on rifting and the associated formation of ocean transform faults - Cretaceous continental extension of the southern margin of Australia. Tectonophysics 359, 131-155. https://doi.org/10.1016/S0040-1951(02)00508-5

Moore, D.H., Betts, P.G., Hall, M., 2016. Constraining the VanDieland microcontinent at the edge of East Gondwana, Australia. Tectonophysics 687, 158-179. https://doi.org/10.1016/j.tecto.2016.09.009

Morley, C.K., 2010. Stress re-orientation along zones of weak fabrics in rifts: An explanation for pure extension in "oblique" rift segments? Earth and Planetary Science Letters 297, 667-673. https://doi.org/10.1016/j.epsl.2010.07.022

Müller, R.D., Seton, M., Zahirovic, S., Williams, S.E., Matthews, K.J., Wright, N.M., Shephard, G.E., Maloney, K.T., Barnett-Moore, N., Hosseinpour, M., Bower, D.J., Cannon, J., 2016. Ocean Basin Evolution and Global-Scale Plate Reorganization Events Since Pangea Breakup. Annual Review of Earth and Planetary Sciences 44, 107-138. https://doi.org/10.1146/annurev-earth-060115-012211

Munro, M.A., Blenkinsop, T.G., 2012. MARD-A moving average rose diagram application for the geosciences. Computers and Geosciences 49, 112-120. https://doi.org/10.1016/j.cageo.2012.07.012

Norvick, M.S., Smith, M.A., Power, M.R., 2001. The Plate Tectonic Evolution of Eastern Australasia Guided by the Stratigraphy of the Gippsland Basin. In: Hill, K.C., Bernecker, T. (Eds.), Eastern Australasian Basins Symposium. Petroleum Exploration Society of Australia, Melbourne, 15-23.

Norvick, M.S., Smith, M.S., 2001. Mapping the plate tectonic reconstruction of southern and southeastern Australia and implications for petroleum systems. The APPEA Journal 41, 
784

O’Brien, G.W., Reeves, C.V., Milligan, P.R., Morse, M.P., Alexander, E.M., Willcox, J.B., Yunxuan, Z., Finlayson, D.M., Brodie, R.C., 1994. New ideas on the rifting history and structural architecture of the western Otway Basin: evidence from the integration of aeromagnetic, gravity and seismic data. The APPEA Journal 34, 529-554. https://doi.org/https://doi.org/10.1071/AJ93042

Peace, A., McCaffrey, K., Imber, J., van Hunen, J., Hobbs, R., Wilson, R., 2018. The role of pre-existing structures during rifting, continental breakup and transform system development, offshore West Greenland. Basin Research 30, 373-394. https://doi.org/10.1111/bre.12257

Philippon, M., Willingshofer, E., Sokoutis, D., Corti, G., Sani, F., Bonini, M., Cloetingh, S., 2015. Slip re-orientation in oblique rifts. Geology 43, 147-150. https://doi.org/10.1130/G36208.1

Phillips, T.B., Jackson, C.A.L., Bell, R.E., Duffy, O.B., 2018. Oblique reactivation of lithosphere-scale lineaments controls rift physiography - The upper-crustal expression of the Sorgenfrei-Tornquist Zone, offshore southern Norway. Solid Earth 9, 403-429. https://doi.org/10.5194/se-9-403-2018

Phillips, T.B., Jackson, C.A.L., Bell, R.E., Duffy, O.B., Fossen, H., 2016. Reactivation of intrabasement structures during rifting: A case study from offshore southern Norway. Journal of Structural Geology 91, 54-73. https://doi.org/10.1016/j.jsg.2016.08.008

Power, M.R., Hill, K.C., Hoffman, N., 2003. Structural inheritance, stress rotation, overprinting and compressional reactivation in the Gippsland Basin - Tuna 3D seismic dataset. The APPEA Journal 43, 197-221. https://doi.org/https://doi.org/10.1071/AJ02010 
Power, M.R., Hill, K.C., Hoffman, N., Bernecker, T., Norvick, M., 2001. The Structural and Tectonic Evolution of the Gippsland Basin: Results from 2D Section Balancing and 3D Structural Modelling. In: Hill, K.C., Bernecker, T. (Eds.), Eastern Australasian Basins Symposium. Petroleum Exploration Society of Australia, Melbourne, 373-384.

Reeve, M.T., Bell, R.E., Duffy, O.B., Jackson, C.A.L., Sansom, E., 2015. The growth of noncolinear normal fault systems; What can we learn from 3D seismic reflection data? Journal of Structural Geology 70, 141-155. https://doi.org/10.1016/j.jsg.2014.11.007

Robin, P.Y.F., Jowett, E.C., 1986. Computerized density contouring and statistical evaluation of orientation data using counting circles and continuous weighting functions. Tectonophysics 121, 207-223. https://doi.org/10.1016/0040-1951(86)90044-2

Rohrbaugh, M.B.J., Dunne, W.M., Mauldon, M., 2002. Estimating fracture trace intensity, density, and mean length using circular scan lines and windows. AAPG Bulletin 86, 2089-2104. https://doi.org/10.1306/61EEDE0E-173E-11D7-8645000102C1865D

Samsu, A., Cruden, A.R., Hall, M., Micklethwaite, S., Denyszyn, S.W., 2019. The influence of basement faults on local extension directions: Insights from potential field geophysics and field observations. Basin Research 31, 782-807. https://doi.org/10.1111/bre.12344

Schiffer, C., Peace, A., Phethean, J., Gernigon, L., McCaffrey, K., Petersen, K.D., Foulger, G., 2018. The Jan Mayen microplate complex and the Wilson cycle. Geological Society, London, Special Publications 470. https://doi.org/10.1144/SP470.2

Sibson, R.H., 1985. A note on fault reactivation. Journal of Structural Geology 7, 751-754. https://doi.org/10.1016/0191-8141(85)90150-6

Stubley, M.P., 1989. Fault and kink-band relationships at Mystery Bay, Australia. Tectonophysics 158, 75-92. https://doi.org/10.1016/0040-1951(89)90317-X 
Teasdale, J.P., Pryer, L., Romine, K., Stuart-Smith, P., Etheridge, M., Loutit, T., Buckingham, A., Shi, Z., Foss, C., Vizy, J., Henley, P., Petrovich, S., Guy-Villon, M., 2004. Australian Southern Margin SEEBASE ${ }^{\mathrm{TM}}$ Compilation, April 2004 [WWW Document]. URL https://data.gov.au/dataset/9131aad8-7d83-4a2b-a678-542e2a1af68a (accessed 6.26.18).

Thiele, S.T., Grose, L., Samsu, A., Micklethwaite, S., Vollgger, S.A., Cruden, A.R., 2017. Rapid, semi-automatic fracture and contact mapping for point clouds, images and geophysical data. Solid Earth 8, 1241-1253. https://doi.org/10.5194/se-8-1241-2017

Thomas, W.A., 2006. Tectonic inheritance at a continental scale. GSA Today 16, 4-11.

Tommasi, A., Vauchez, A., 2001. Continental rifting parallel to ancient collisional belts: an effect of the mechanical anisotropy of the lithospheric mantle. Earth and Planetary Science Letters 185, 199-210. https://doi.org/10.1016/S0012-821X(00)00350-2

Tveite, H., 2015. The QGIS Line Direction Histogram Plugin [WWW Document]. URL http://arken.nmbu.no/ havatv/gis/qgisplugins/LineDirectionHistogram/ (accessed 7.26.16)

Van Noten, K., Van Baelen, H., Sintubin, M., 2012. The complexity of 3D stress-state changes during compressional tectonic inversion at the onset of orogeny. Geological Society Special Publication 367, 51-69. https://doi.org/10.1144/SP367.5

VandenBerg, A.H.M., Cayley, R.A., Willman, C.E., Morand, V.J., Seymon, A.R., Osborne, C.R., Taylor, D.H., Haydon, S.J., McLean, M., Quinn, C., Jackson, P., Sandford, A.C., 2006. Walhalla-Woods Point-Tallangallook special map area geological report, Geological Survey of Victoria Report 127. GeoScience Victoria. Department of Primary Industries. 
VandenBerg, A.H.M., Willman, C.E., Maher, S., Simons, B.A., Cayley, R.A., Taylor, D.H., Morand, V.J., Moore, D.H., Radojkovic, A., 2000. The Tasman Fold Belt System in Victoria. Geological Survey of Victoria Special Publication 462.

Vollgger, S., Cruden, A., 2019. Cape Liptrap orthomosaic. https://doi.org/https://doi.org/10.26180/5c653193efa25

Vollgger, S.A., Cruden, A.R., 2016. Mapping folds and fractures in basement and cover rocks using UAV photogrammetry, Cape Liptrap and Cape Paterson, Victoria, Australia. Journal of Structural Geology 85, 168-187. https://doi.org/10.1016/j.jsg.2016.02.012

Watkins, H., Bond, C.E., Healy, D., Butler, R.W.H., 2015. Appraisal of fracture sampling methods and a new workflow to characterise heterogeneous fracture networks at outcrop. Journal of Structural Geology 72, 67-82. https://doi.org/10.1016/j.jsg.2015.02.001

Welch, M.J., Souque, C., Davies, R.K., Knipe, R.J., 2014. Using mechanical models to investigate the controls on fracture geometry and distribution in chalk. Geological Society, London, Special Publications 406, 281-309. https://doi.org/10.1144/sp406.5

Whipp, P.S., Jackson, C.A.L., Gawthorpe, R.L., Dreyer, T., Quinn, D., 2014. Normal fault array evolution above a reactivated rift fabric; a subsurface example from the northern Horda Platform, Norwegian North Sea. Basin Research 26, 523-549. https://doi.org/10.1111/bre.12050

Willcox, J.B., Colwell, J.B., Constantine, A.E., 1992. New ideas on Gippsland Basin regional tectonics. Gippsland Basin Symposium 22-23 June 1992. Melbourne, 93-110.

Willcox, J.B., Stagg, H.M.J., 1990. Australia's southern margin: a product of oblique extension. Tectonophysics 173, 269-281. https://doi.org/10.1016/0040-1951(90)90223- 
877

878

880

881

882

883

884

885

886

887

888

889

890

891

892

893

894

895

896

897

Williams, J.N., Fagereng, Å., Wedmore, L.N.J., Biggs, J., Mphepo, F., Dulanya, Z., Mdala, H., Blenkinsop, T., 2019. How Do Variably Striking Faults Reactivate During Rifting? Insights From Southern Malawi. Geochemistry, Geophysics, Geosystems 2019GC008219. https://doi.org/10.1029/2019GC008219

Williams, S.E., Whittaker, J.M., Müller, R.D., 2011. Full-fit, palinspastic reconstruction of the conjugate Australian-Antarctic margins. Tectonics 30. https://doi.org/10.1029/2011TC002912

Wilson, C.J.L., Moore, D.H., Luzin, V., Salvemini, F., 2017. Costerfield antimony-gold deposit, southeast Australia: Coupling between brittle deformation and dissolutionprecipitation reactions in the Melbourne Zone. Ore Geology Reviews 91, 741-764. https://doi.org/10.1016/j.oregeorev.2017.08.024

Wilson, J.T., 1966. Did the Atlantic Close and then Re-open? Nature 211, 676-681.

Wilson, R.W., Holdsworth, R.E., Wild, L.E., McCaffrey, K.J.W., England, R.W., Imber, J., Strachan, R.A., 2010. Basement-influenced rifting and basin development: a reappraisal of post-Caledonian faulting patterns from the North Coast Transfer Zone, Scotland. Geological Society, London, Special Publications 335, 795-826. https://doi.org/10.1144/SP335.32

Wilson, R.W., McCaffrey, K.J.W., Holdsworth, R.E., Imber, J., Jones, R.R., Welbon, A.I.F., Roberts, D., 2006. Complex fault patterns, transtension and structural segmentation of the Lofoten Ridge, Norwegian margin: Using digital mapping to link onshore and offshore geology. Tectonics 25, 1-28. https://doi.org/10.1029/2005TC001895

Wu, H., Pollard, D.D., 1995. An experimental study of the relationship between joint spacing 

and layer thickness. Journal of Structural Geology 17, 887-905. https://doi.org/10.1016/0191-8141(94)00099-L 
902 Table 1 Summary of the sequence of ductile and brittle deformation at Shark Stack. The

903 orientation of the traces of the structures on aerial imagery, the sense of movement along the 904 horizontal, and the inferred orientation of the maximum horizontal principal stress $\left(\sigma_{\mathrm{H}}\right)$ are 905 included.

Event Structures Trace Azimuth $\begin{gathered}\text { Sense of } \\ \text { Movement }\end{gathered}$ Regime $\sigma_{\mathrm{H}}$ Orientation

\begin{tabular}{lccllll}
\hline D1 & F1 folds & NNE-SSW & $003-037^{\circ}$ & & Contraction & WNW-ESE \\
D2 & F2 kink folds & N-S & $355-015^{\circ}$ & Dextral & Contraction & NNE-SSW \\
D3 & Fractures & ENE-WSW & $050-075^{\circ}$ & Dextral & Extension & ENE-WSW \\
D4 & F4 kinks & NW-SE & $310-320^{\circ}$ & Dextral & Contraction & NNW-SSE \\
D4 & Fractures & NNW-SSE & $315-360^{\circ}$ & Sinistral & Contraction & NNW-SSE
\end{tabular}


907 Table 2 Fracture trends in Lower Cretaceous Strzelecki Group outcrops. $\mathrm{N}_{\mathrm{L} \leq 50 \mathrm{~m}}=$ total

908 number of fracture traces at each locality with a length $\leq 50 \mathrm{~m} ; \mathrm{N}_{\text {Trend }}=$ number of fracture 909 traces belonging to the corresponding trend.

\begin{tabular}{lcccc} 
Locality & $\mathbf{N}_{\mathrm{L} \leq \mathbf{5 0 \mathbf { m }}}$ & \multicolumn{2}{c}{ Trend Azimuth } & $\mathbf{N}_{\text {Trend }}$ \\
\hline Harmers Haven North & 1308 & NNW-SSE & $335-350^{\circ}$ & 267 \\
& & WNW-ESE & $280-295^{\circ}$ & 246 \\
& & E-W & $080-100^{\circ}$ & 259 \\
\hline Harmers Haven South & 2497 & NNW-SSE & $325-345^{\circ}$ & 1055 \\
\hline Eagles Nest & 1443 & NNW-SSE & $325-345^{\circ}$ & 404 \\
& & ENE-WSW & $065-080^{\circ}$ & 180 \\
& & E-W & $080-095^{\circ}$ & 188 \\
\hline The Caves - Flat Rocks & 1591 & NNW-SSE & $320-345^{\circ}$ & 522 \\
& & ENE-WSW & $065-085^{\circ}$ & 239 \\
& & NNE-SSW & $010-020^{\circ}$ & 126 \\
\hline Inverloch & 378 & NW-SE to NNW-SSE & $315-345^{\circ}$ & 141 \\
& & E-W & $085-090^{\circ}$ & 27 \\
& & WNW-ESE to NW-SE & $290-315^{\circ}$ & 86
\end{tabular}




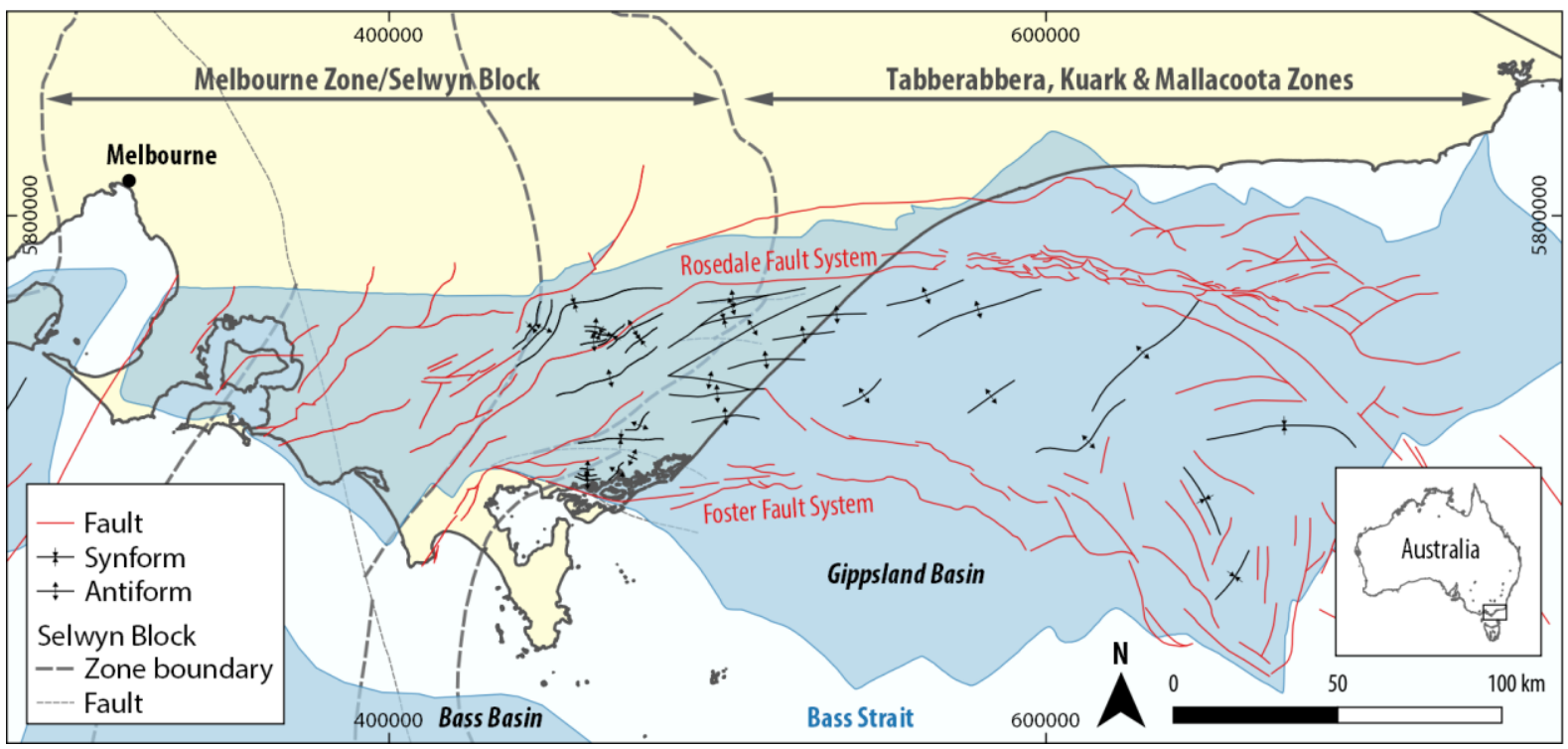

912 Figure 1 Location and major structures of the Cretaceous Gippsland Basin and the nearby 913 Bass Basin (shaded in blue). Areas that are underlain by the Selwyn Block (Moore et al., 914 2016) and Melbourne Zone are shaded in grey. Faults and folds in the Gippsland Basin are 915 modified after Constantine (2001) and Power et al. (2001). From west to east, the trends of 916 fault traces change from NE-SW and ENE-WSW (western onshore Gippsland Basin), to E-W 917 and NW-SE (eastern onshore and offshore Gippsland Basin); this transition defines, in part, 918 the eastern margin of the Selwyn Block (Cayley et al., 2002). The coordinate reference 919 system is GDA94 / MGA zone 55. 


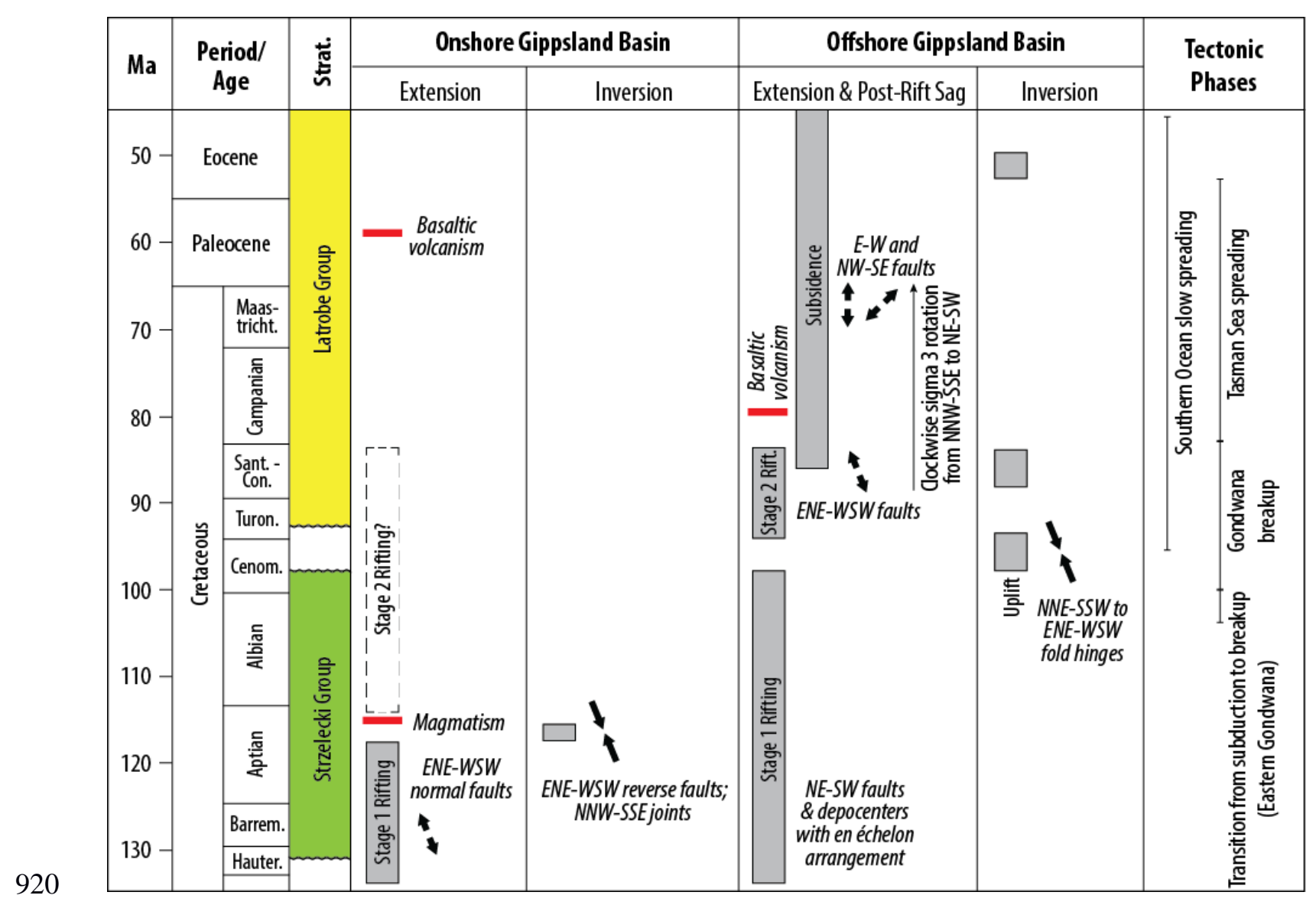

921 Figure 2 Summary of the deformation history in the Gippsland Basin and associated tectonic 922 events. Deformation events in the offshore Gippsland Basin and basaltic volcanism are 923 derived from seismic reflection studies (Norvick et al., 2001; Power et al., 2003). Early 924 Cretaceous deformation and magmatism in the onshore Gippsland Basin are derived from 925 field studies and regional potential field geophysics (Samsu et al., 2019). Arrows indicate 926 local extension and shortening directions inferred from fault orientations. 


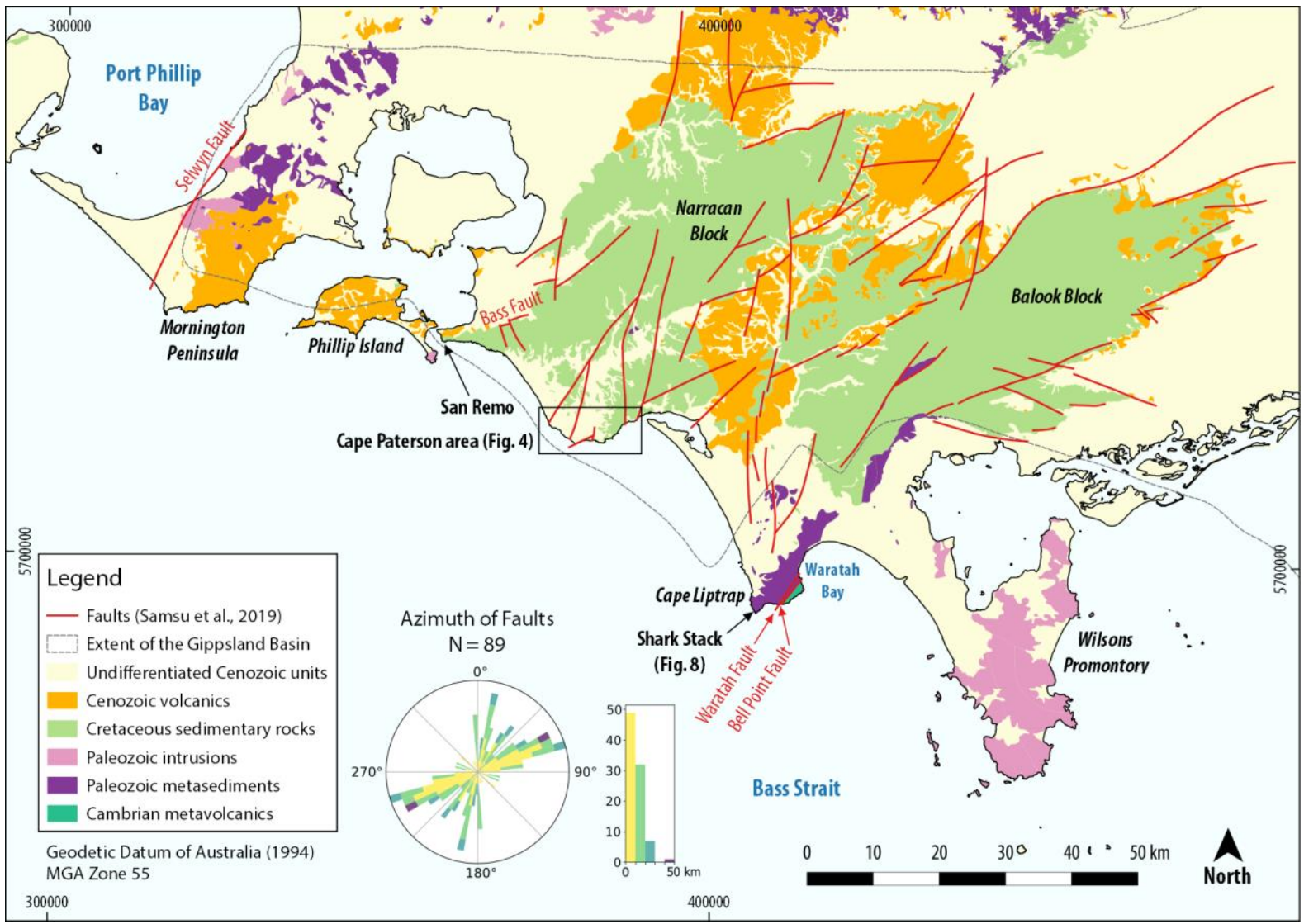

928 Figure 3 Map of basin-scale (>1 km-scale) faults interpreted from magnetic and gravity data 929 (modified after Samsu et al., 2019). The rose diagram of fault traces was created using the 930 GeoTrace plugin (Thiele et al., 2017) in QGIS and is coloured by fault length. Colours on the 931 rose diagram correlate with fault length bins shown on the length histogram. The coordinate 932 reference system is GDA94 / MGA zone 55. 


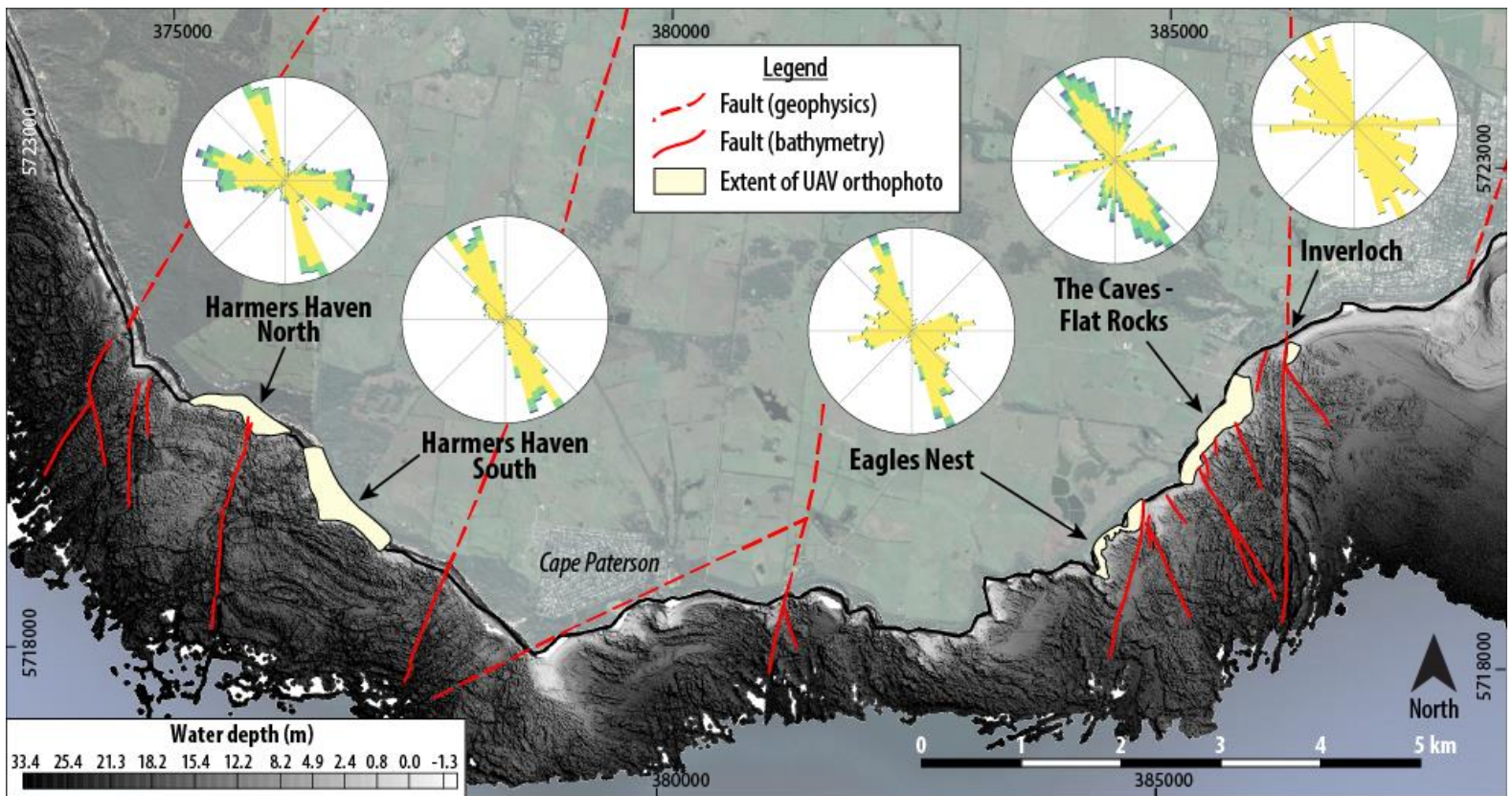

934 Figure 4 Map of the UAV photogrammetry survey areas, where outcrop-scale fractures in the 935 Lower Cretaceous Strzelecki Group were traced, overlain on a greyscale image of near-shore 936 bathymetry (modified after Samsu et al., 2019). The frequency of the orientations of fracture 937 traces from each area is visualised as length-coloured rose diagrams. Colours correspond to 938 fracture length, subdivided into $10 \mathrm{~m}$ bins (see Fig. 5 for colour ramp of length bins). See Fig. 9393 for location of map. 

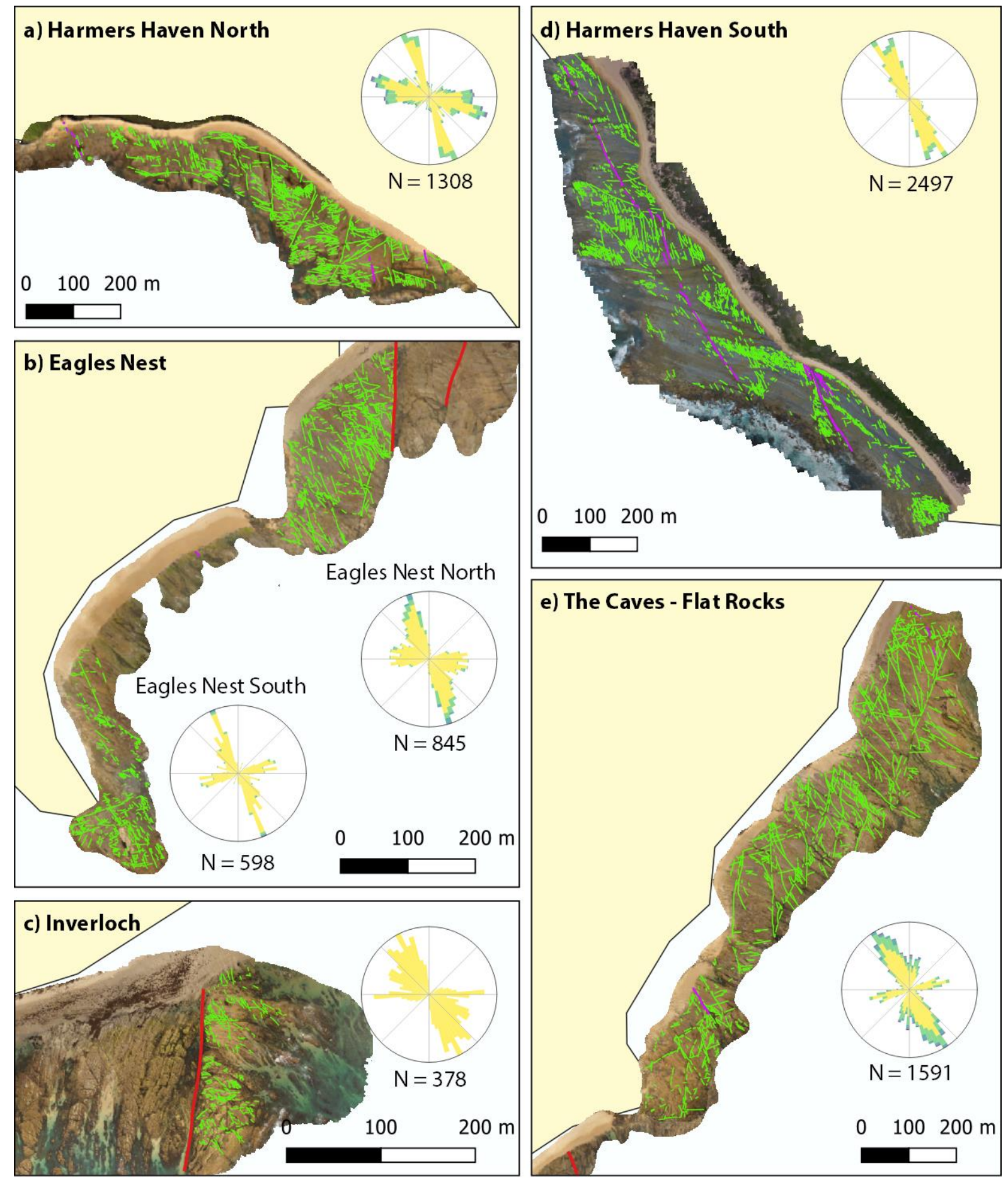

Fracture trace length bins
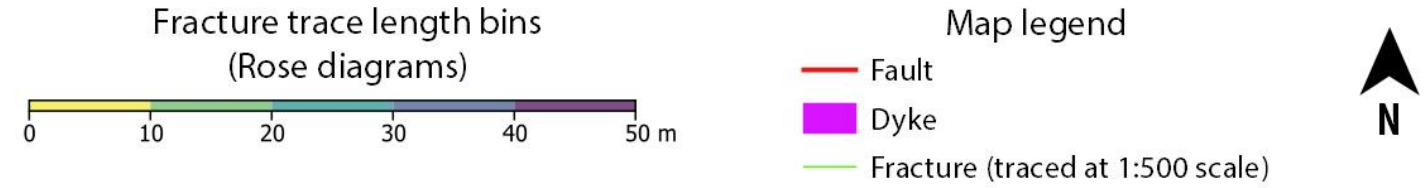

941 Figure 5 Fracture trace maps and rose diagrams, representing fractures $<50 \mathrm{~m}$ in length, for

942 the five studied outcrops (see Fig. 4 for locations). Fracture traces (interpreted at a scale of 943 1:500) are overlain on UAV orthophotos. Colours on the rose diagram correspond to fracture 944 length, subdivided into $10 \mathrm{~m}$ bins. 


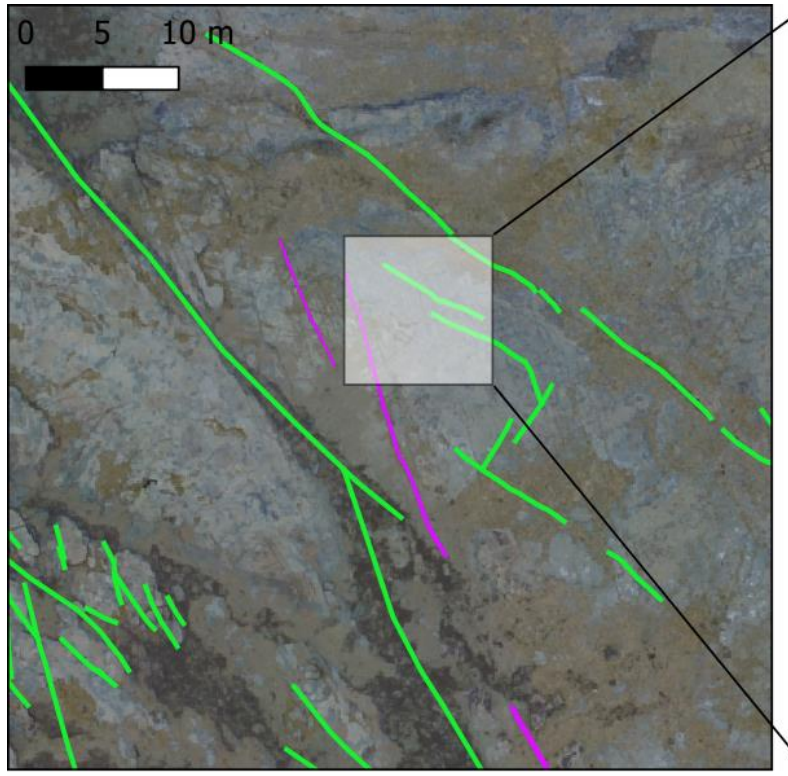

$1: 500$ scale

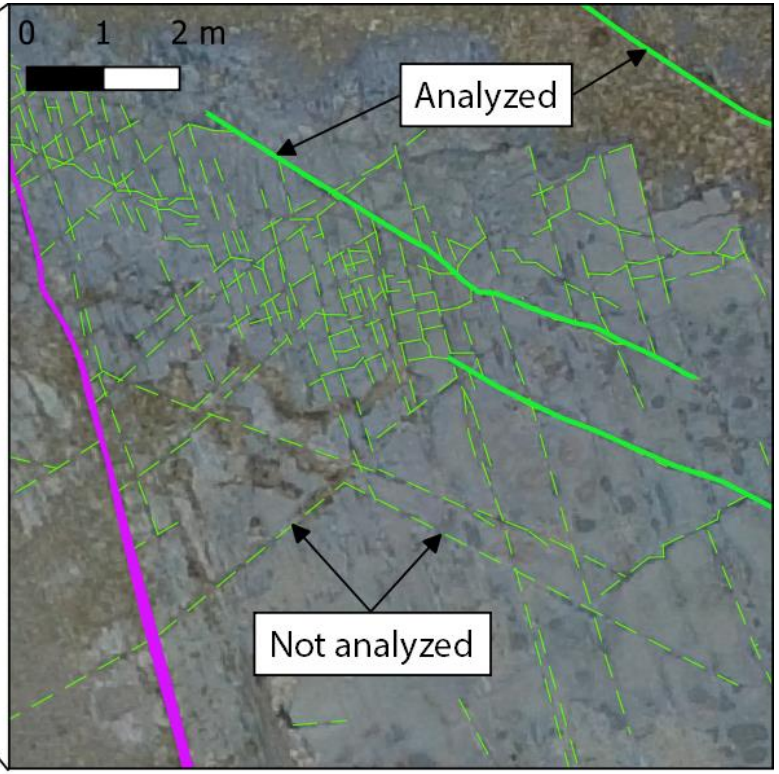

$1: 100$ scale

946 Figure 6 Fracture traces (green) interpreted from UAV orthophotos at 1:500 and 1:100 zoom 947 levels. Fractures that can be seen at the 1:500 scale (thick, continuous lines) were included in 948 the analyses of fracture orientations, so that we only compare fractures between outcrops that 949 are observable at the same scale. Purple traces represent mafic dykes. 

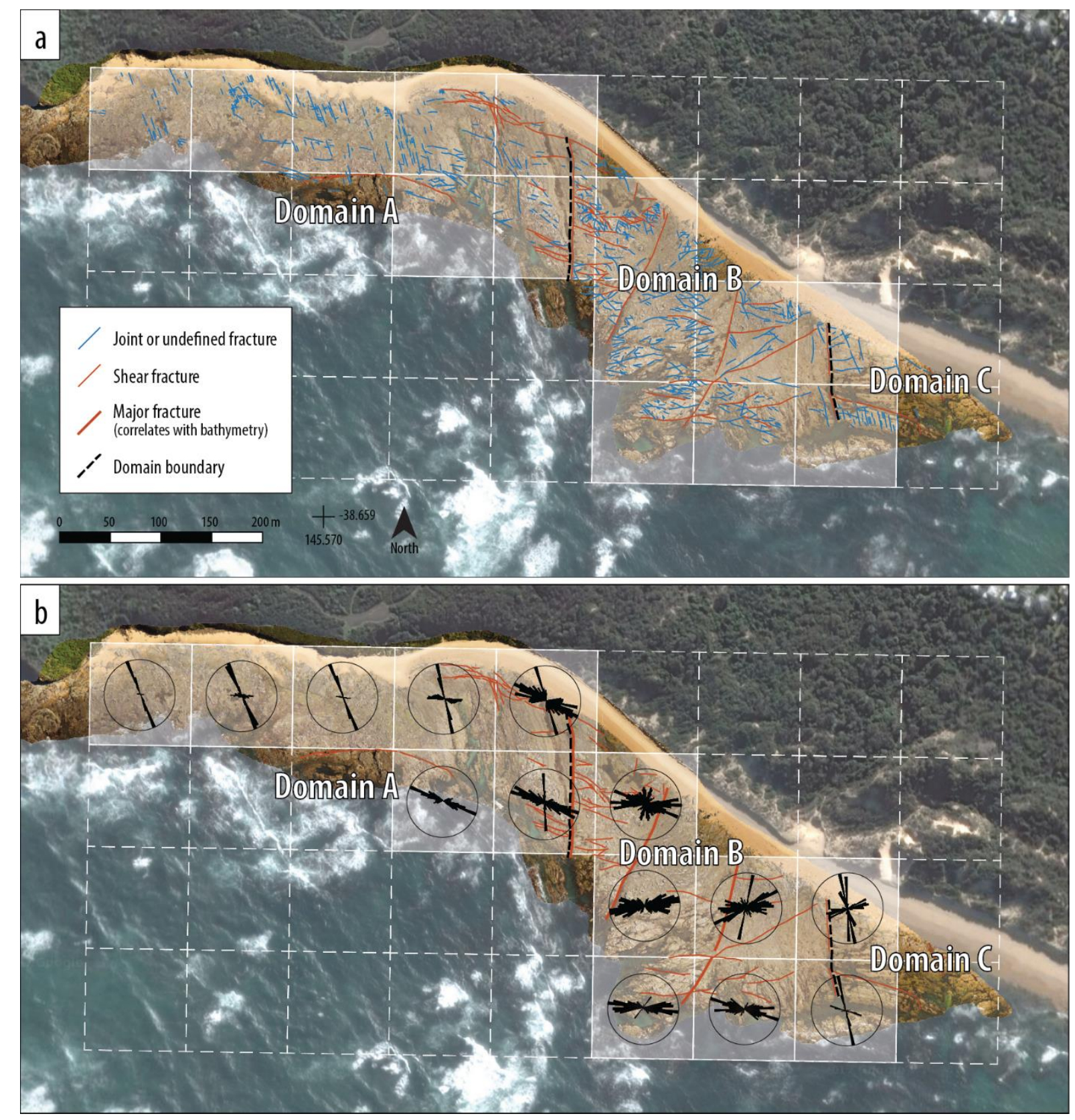

951 Figure 7 (a) Fracture trace map of the Harmers Haven North locality. The basemap is a high952 resolution ( $3 \mathrm{~cm} /$ pixel) UAV orthophoto. A grid made up of $100 \mathrm{~m} \times 100 \mathrm{~m}$ tiles is overlain 953 on the orthophoto. (b) Length-weighted rose diagrams of fracture trace orientations calculated 954 for each tile using the Line Direction Histogram plugin (Tveite, 2015) in QGIS. The 955 background is a satellite image (source: Google Earth, $38.657362^{\circ}$ and $145.572051^{\circ}$, May 14 , 956 2016, accessed July 30, 2017). 

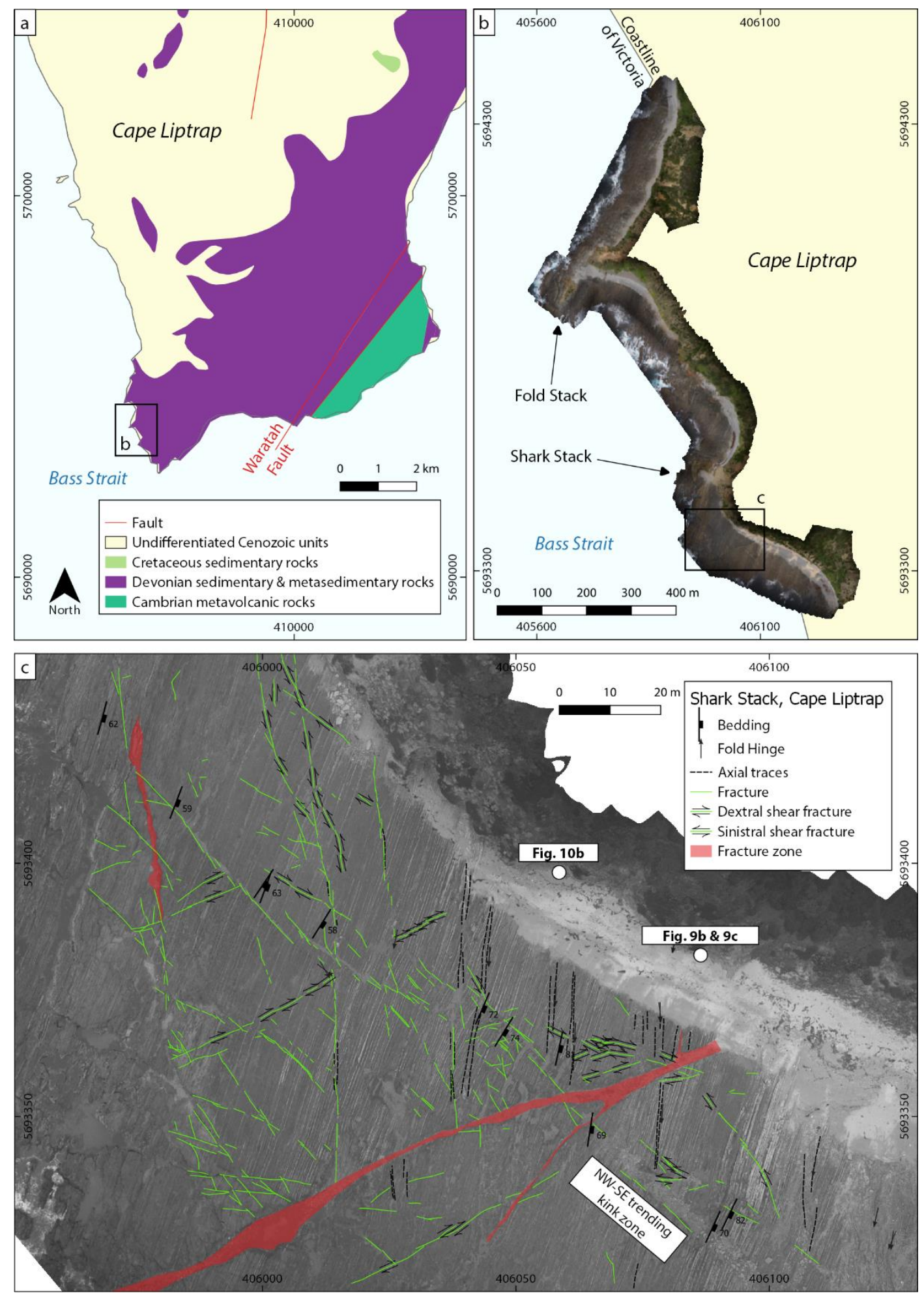

958 Figure 8 (a) Location of Shark Stack study area at the southwestern end of Cape Liptrap (see 959 Fig. 3 for location), where a UAV orthophoto (b; $2 \mathrm{~cm} /$ pixel) was used as a basemap for 960 structural mapping in the field. Structures at the Fold Stack locality have been described in 961 detail in Vollgger and Cruden (2016). (c) Map of fractures, axial traces of folds, and 962 structural measurements at Shark Stack. All of the fractures that are visible at a 1:500 scale 963 are shown. 


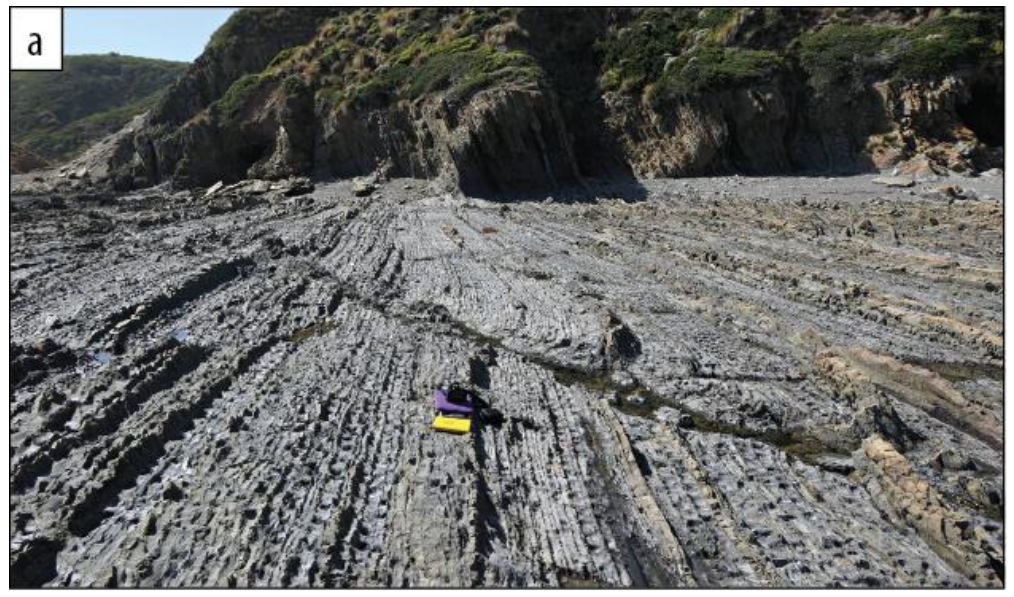

(d) Poles to bedding $\left(S_{0}\right) \&$ F1 fold axis
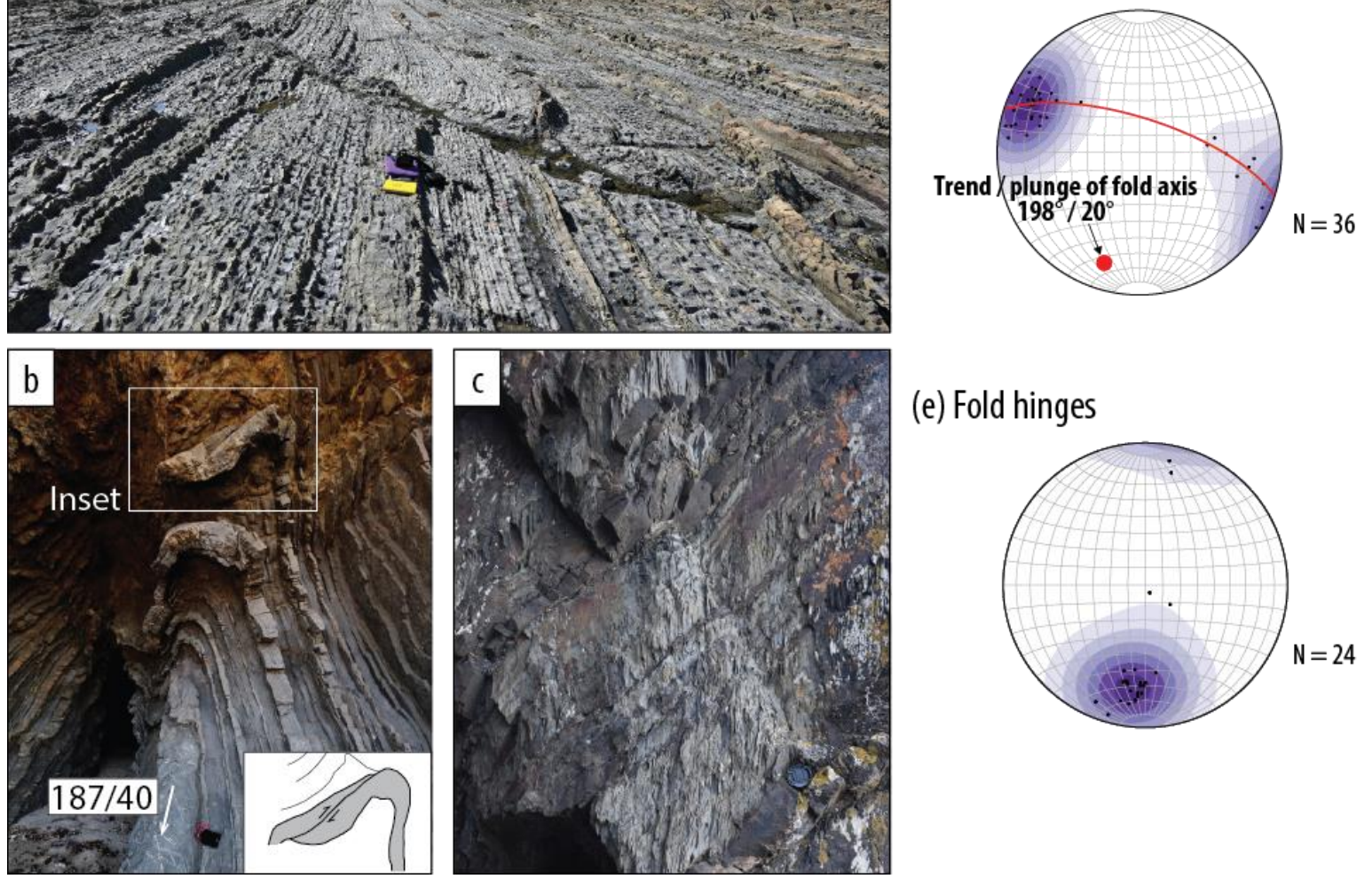

(e) Fold hinges

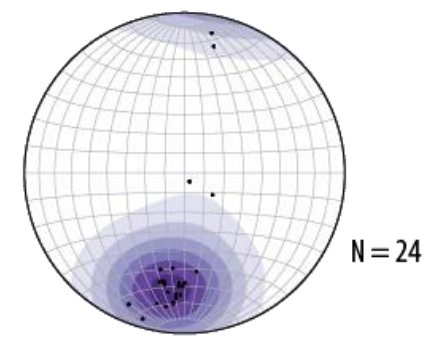

965 Figure 9 Structures at Shark Stack, Cape Liptrap: (a) Photograph of steeply dipping,

966 alternating beds of sandstone and mudstone cropping out on a horizontal wavecut platform

967 and along vertical cliff faces. These rocks form the Devonian basement underlying the

968 onshore Gippsland Basin. (b) Photograph of disharmonic F2 folds exposed in a cliff face. The

969 inset shows a fold accommodation fault offsetting a sandstone bed in a reverse sense near the

970 fold hinge. The arrow indicates the measured orientation of the hinge line. (c) Photograph of

971 axial planar cleavage and parasitic folds on the limb of an F1 fold. (d) Plot of poles to

972 bedding measurements and the axis of a first-order F1 fold calculated from bedding

973 measurements. (e) Plot of measured fold hinges; F2 kink fold hinges associated with a D2

974 contractional event plunge shallowly to the south. Subvertical fold hinges may be associated

975 with slump folds and are therefore non-tectonic in nature. Pole orientations were contoured

976 using the Exponential Kamb method at intervals of $3 \sigma$. 


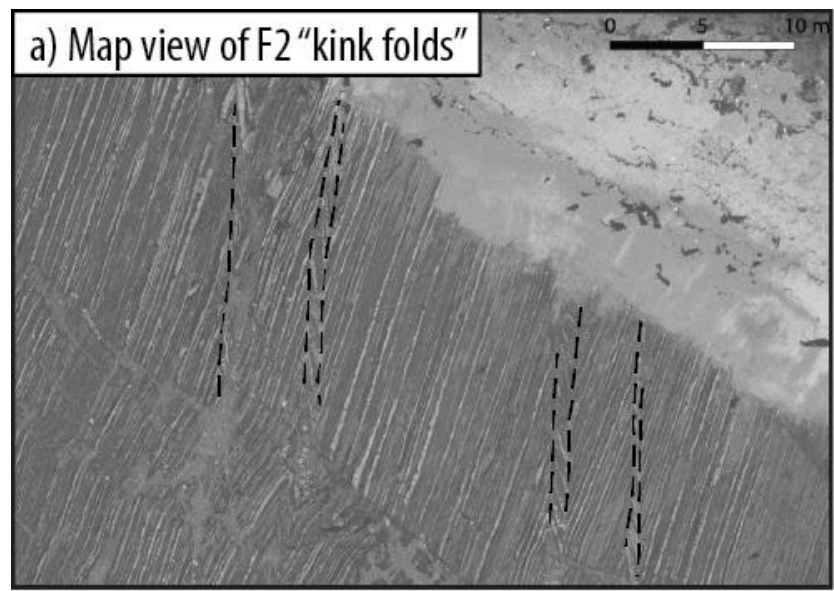

c) Uniaxial loading experiments on nanolamellar pearlitic steel

Kapp et al. (2016) Load

\section{b) Cross section view of F2 folds}
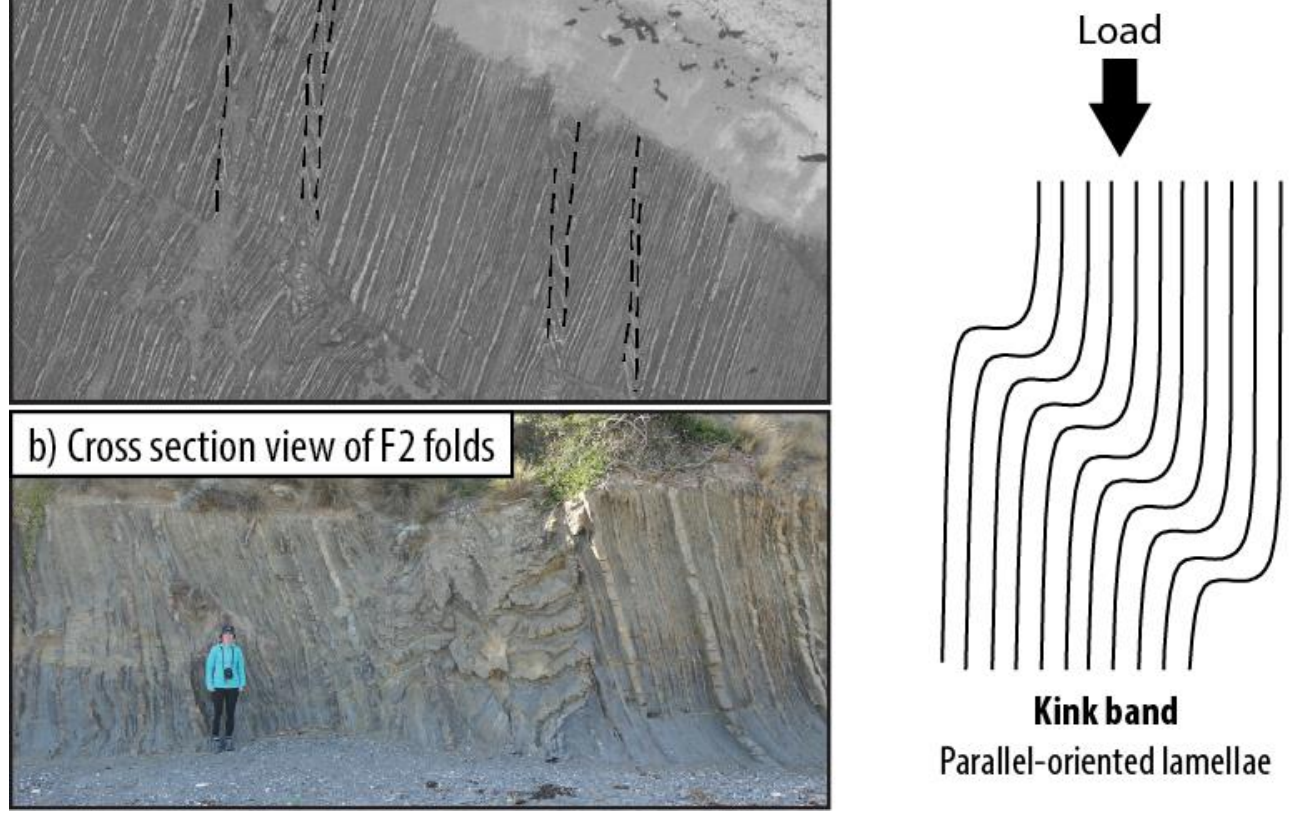

Kink band

Parallel-oriented lamellae

978 Figure $10 \mathrm{~N}-\mathrm{S}$ trending zones of kinking in the wavecut platform (a) and cliff (b). Dashed 979 lines represent axial traces of F2 kink folds. Kink folds at Shark Stack are analogous to kink 980 bands in nanolamellar pearlitic steel (c) (modified after Kapp et al., 2016). 


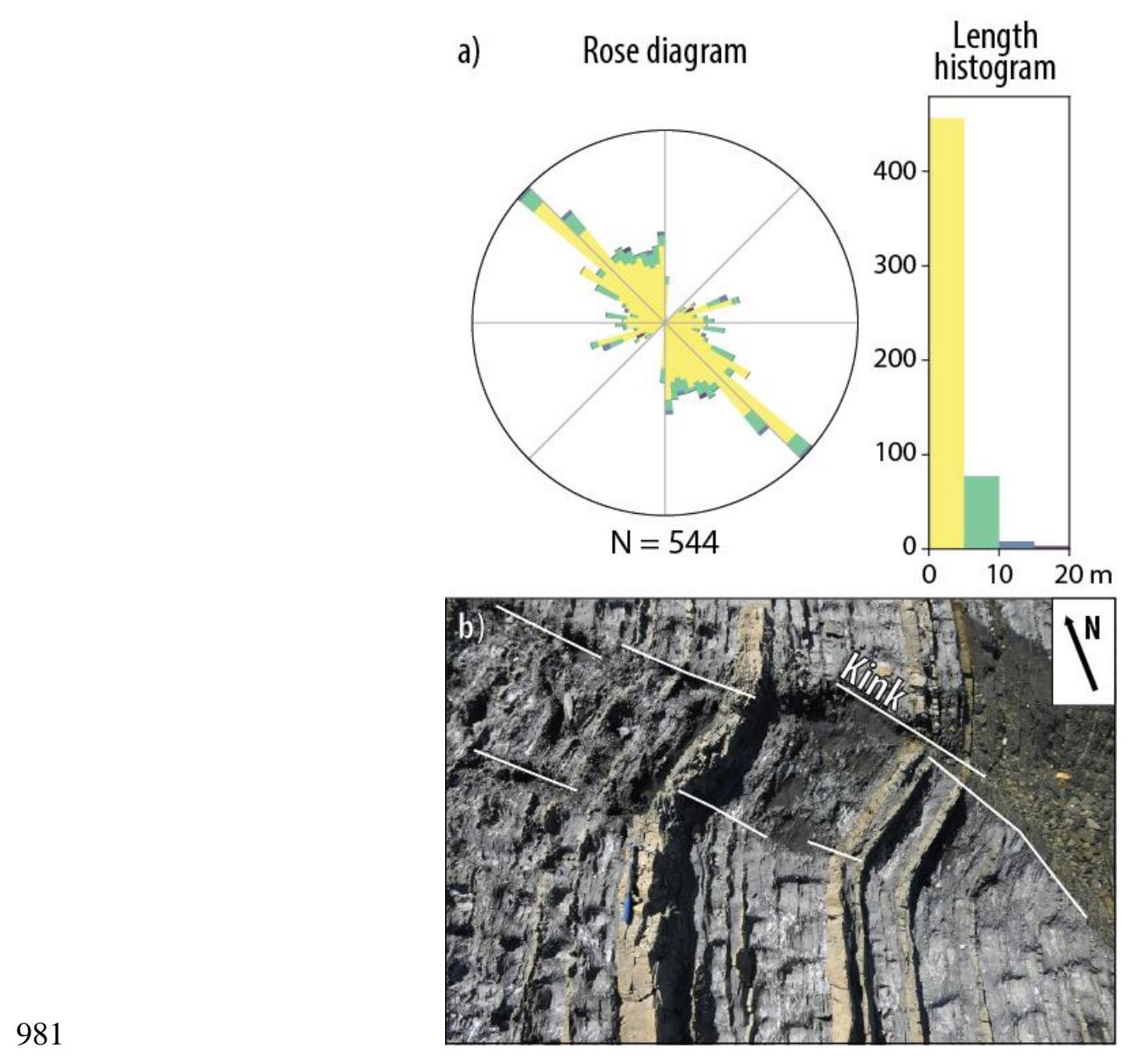

982 Figure 11 (a) Length-coloured rose diagram of outcrop-scale fractures at Shark Stack. (b) 983 The NW-SE trending peak represents a large population of kinks that make up the NW-SE 984 trending F3 kink bands. The length-coloured rose diagram allows us to assign fractures of 985 different length ranges to certain orientation trends. NW-SE kinks are <10 $\mathrm{m}$ in length, most 986 of them being shorter than $5 \mathrm{~m}$. Fractures that are longer than $10 \mathrm{~m}$ trend NNW-SSE and 987 ENE-WSW. 

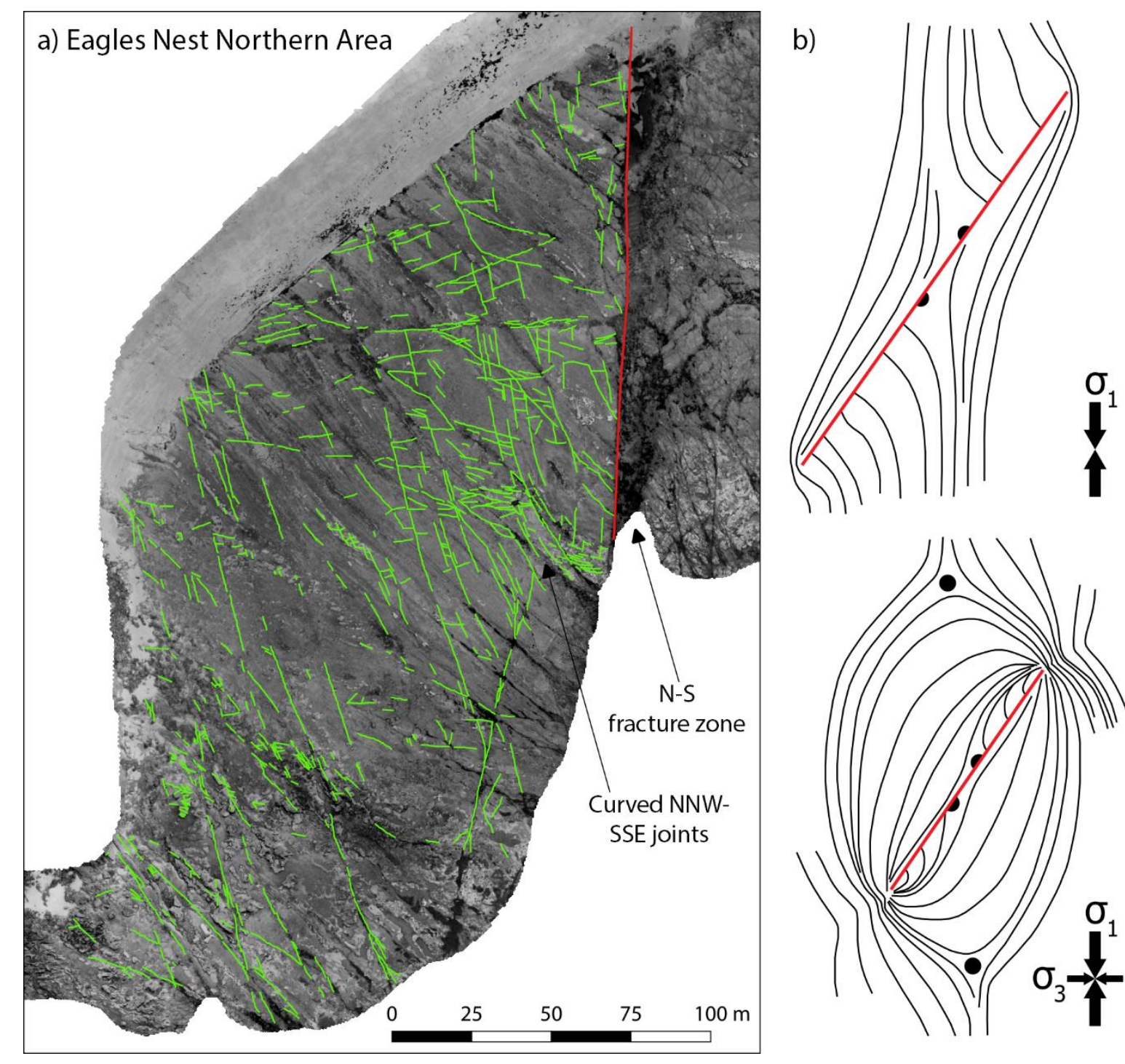

988

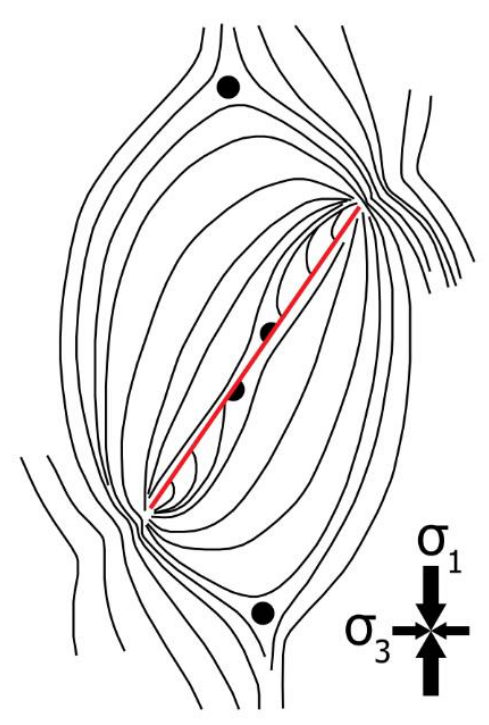

Figure 12 (a) Fracture traces at the northern part of the Eagles Nest locality, overlain on a

990 high-resolution (3.2 cm/pixel) UAV orthophoto (See Fig. 4 for location). Veering of NNW-

991 SSE trending joints in the vicinity of the large N-S trending fault is observed, which may be 992 caused by perturbed stress trajectories around the larger fault. A similar phenomenon has

993 been observed in photoelastic experiments of uniaxial and biaxial loading on analogue

994 materials (b; modified from de Joussineau et al., 2003). The red line represents a pre-existing

995 fault, and black circles and half circles are isotropic points. 
a) Cross-section

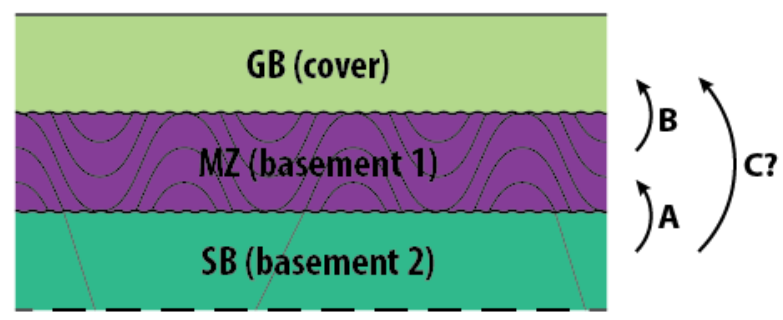

A. Reactivation of SB faults influenced MZ faults

B. MZ faults and fabric influenced GB faults

C. Anomalously strong SB influenced GB faults?

b) Plan-view

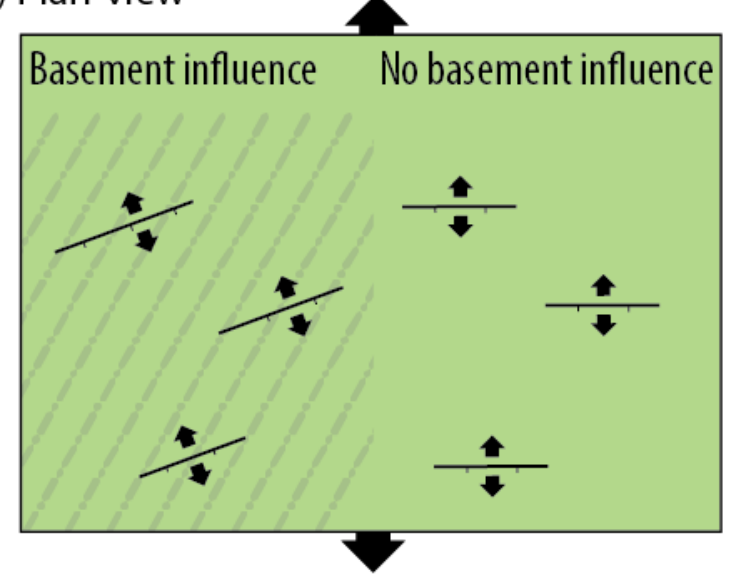

997 Figure 13 (a) Schematic cross section demonstrating the influence of different basement 998 units on overlying units. Devonian faulting in the Melbourne Zone could have been

999 controlled by the reactivation of pre-existing Cambrian faults in the Selwyn Block (A). The

1000 complex array of Early Cretaceous normal faults could have resulted from local stress re-

1001 orientation above Devonian faults and penetrative fabrics in the Melbourne Zone (B). It

1002 remains unclear how the relatively high strength of the Selwyn Block, juxtaposed against the

1003 weaker surrounding lower crust, could have affected Early Cretaceous rifting (C). GB =

1004 Gippsland Basin; MZ = Melbourne Zone; SB = Selwyn Block. (b) Schematic map-view

1005 illustration of normal fault orientations: They are oblique to the regional extension direction

1006 above an anisotropic basement, but they are orthogonal to regional extension where the

1007 basement is less influential. 


\section{Extension}

a)

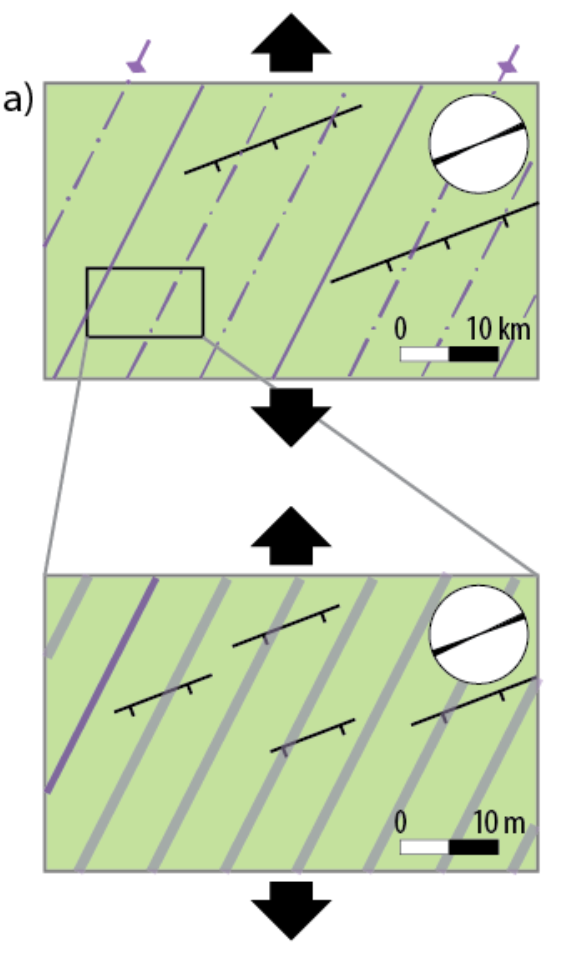

Shortening

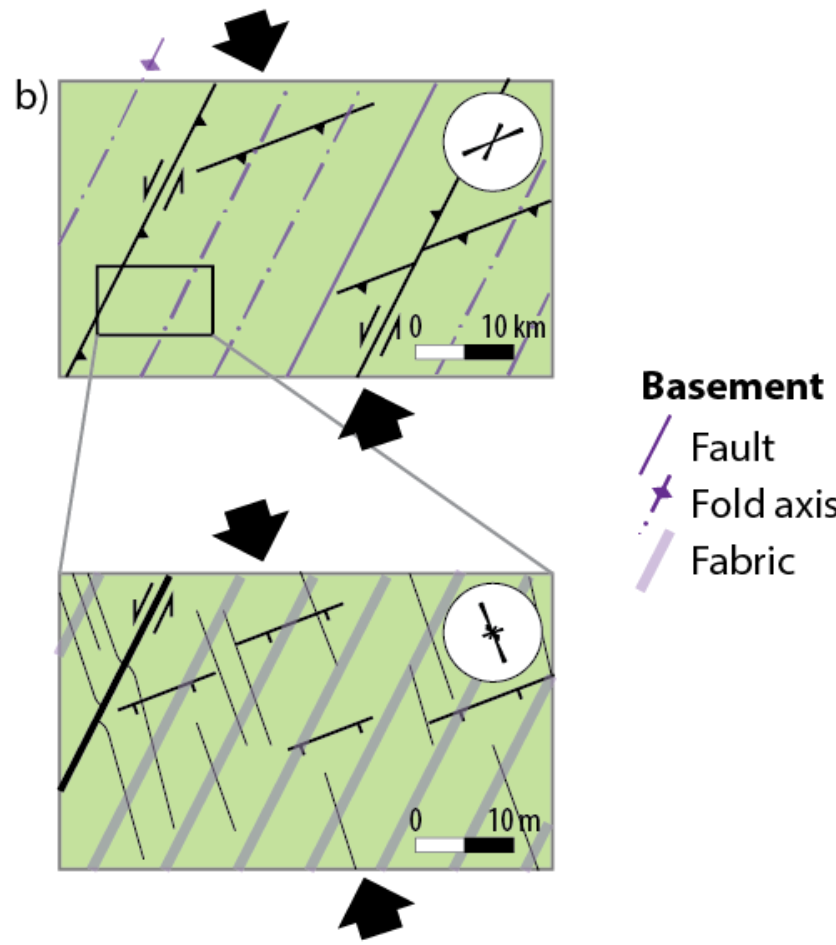

1009 Figure 14 Plan-view schematic illustration of fracture traces in the cover - associated with 1010 Early Cretaceous extension (a) followed by shortening (b) - and their trends. The purple lines 1011 represent structures in the underlying Melbourne Zone basement. Extension-related fractures 1012 show the same ENE-WSW trend at basin scale (>1 km) and outcrop scale (meters-scale). 1013 During subsequent shortening, pre-existing basement structures and rift-related ENE-WW 1014 trending fractures are reactivated, so that new fractures are localised above or near reactivated 1015 structures at the basin scale. At outcrop scale, new sub-vertical joints formed parallel to the direction of regional compression, though some joints veer towards larger, pre-existing faults. 